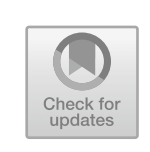

\title{
Positing Cartesianism as an Ontology Within Science Education: Towards a More Response-Able Inheritance with Dr. Frédérique Apffel-Marglin
}

Inheritance is never a given, it is always a task. It remains before us just unquestionably as we are heirs..., even before wanting or refusing to be, and, like all inheritors, we are in mourning... To be, this word... means, ...to inherit. All of the questions on the subject of being or of what is to be (or not to be) are questions of inheritance. (Derrida, 1994/2006, p. 76, emphasis in original)

Before getting on to the work of positing an (other) ontology that might be more commensurate with Indigenous science (to-come) in the next chapter of this book, the purpose of this chapter is to continue the task undertaken in the previous chapter: tinkering with/in the multicultural science education debate using ontology towards a more response-able science education. As "all of the questions on the subject of being or of what is to be (or not to be) are questions of inheritance" (Derrida, $1994 / 2006$, p. 76), the task of this chapter is to engage in the historical homework of response-ability by archaeologically digging into the historicity and operationalization of our ontological inheritance: Cartesianism. In order to investigate the question of what might it mean to account for and be accountable to an ontology of Cartesianism?, we must also ask productively entangled questions such as: How, where, and when

M. Higgins, Unsettling Responsibility in Science Education, Palgrave Studies in Educational Futures, https://doi.org/10.1007/978-3-030-61299-3_6 
did Cartesianism as "common sense" become common? How was Cartesianism produced?, How did we come to inherit Cartesianism?, and What does it make producible? These questions bear significance as Cartesianism is not only the ontology of WMS, but also deeply shapes the ways in which science education attempts to engage with the very ways-ofknowing-in-being that it continues to Other. We are its inheritors in science education, "even before wanting or refusing to be" (Derrida, $1994 / 2006$, p. 76)—our relation to this ontology is irreducible, whether we acknowledge it or not, desire it or not. To account for and be accountable to Cartesianism is part and parcel of science education's homework of response-ability: this ontology lingers and lurks even as we attempt to move within, against, and beyond it. To leave Cartesianism unaddressed risks rendering decolonizing moves, de/colonizing. ${ }^{1}$

Thus, in order to continue this tinkering (i.e., using that which might be intended for other uses) with ontological absent presences, I trace our ontological inheritance. Specifically, how multiple there-thens of Cartesian "origins" are haunt the here-now of science education: passed over pasts which constitute our inheritance. However, inheritance and responsibility are irreducibly related: "there is no inheritance without a call to responsibility" (Derrida, 1994/2006, p. 114). It is call to engage in "creative archeology, a performative reinvention, of the received wisdoms that constitute our cultural inheritance" (Kirby, 2012, p. 198) which (re)produces who science educators are and can be. It is to engage in the homework of response-ability with attentiveness to our history; particularly, the ways in which past is not yet past and should not be passed over.

Significantly, "inheritance is never given, it is always a task" (Derrida, 1994/2006, p. 67, emphasis in original): the task of inheritance is not one that is straightforward when our onto-epistemic inheritances present themselves as absent presences, normalized and naturalized through centuries of Eurocentric thought and colonial practice (such as is the case in science education; see Higgins \& Tolbert, 2018). ${ }^{3}$ Thus, to engage with the task of (re)opening the norms of responsiveness towards Indigenous science to-come, attention is brought to how Cartesianism plays, has played, and will play an active role in the (fore)closure of response-ability: the task of inheritance. To undertake this ontological homework of response-ability, I draw from a series of expert interviews with Dr. Frédérique Apffel-Marglin's that unpack the historical, geographical, political, economic, and religious forces of the "birth of 
modernity" and reveal the ways in which this "common sense" went from being uncommon to common and continues to persist. In turn, these insights are read, or more specifically diffracted, through the multicultural science education debate in order to (re)open the space for responsiveness therein. In thinking with Dr. Frédérique Apffel-Marglin, I make the argument that the making common of Cartesianism not only (fore)closes the possible possibilities for responding to Indigenous science to-come, but also to account for and be accountable to the ontology of WMS and what it produces.

Before this diffractive reading, I present a positional vignette to both introduce the work to come and my (co-constitutive) relation to the work herein. A methodological section on (re)thinking expert interview diffractively follows.

\section{Pathways of Chance: Encountering Dr. Frédérique ApfFel-Marglin}

What if we leave room in our lives for chance and the unexpected?.... Instead of seeing' one's life planned out into the future like a vast highway, life only makes sense to us when we look back to the past and see the path we have taken with all its diversion, U-turns and side roads. There may have been no fixed plan for the future but looking back at the map of one's life journey it almost seems as if there had indeed been a goal all along, but a goal that had been concealed at every step of the way. (Peat, 2007, pp. 15-16)

Because we must "begin" some-where and some-time, let's "begin" in Lamas, Peru in June of $2013 .{ }^{4}$ Then and there, I would have the pleasure of interviewing Dr. Frédérique Appfel-Marglin on her work around deconstructing the metaphysics of modernity as well as what can be learned through attending to ritualized action. For me, this would be what Peat (2007) refers to as a "pathway of chance".

As Peat (2007) elaborates in his "little" autobiography, our lived experiences cannot be mapped so easily: we are always walking along pathways of chance. A probabilistic approach might see us treading common paths more often than those uncommon. However, when we encounter the uncommon "do we compensate as best we can in an attempt to remain on our predetermined track?" (p. 15). Peat suggests that if "we leave room 
in our lives for chance and the unexpected" (p. 15), we may come to encounter new relationships as well as old relations anew. Such encounters can gently inflect our life's journey or throw into new directions altogether, into unanticipated spaces and places that we may only be able to make sense of in retrospect, if at all. Just as Peat's life was thrown into another orbit altogether through meeting his mentor-to-be David Bohm, as well as the Blackfoot peoples (and Blackfoot scholars like Leroy Little Bear), my encountering Dr. Frédérique Appfel-Marglin was a meeting of the latter pivotal type.

I first textually encountered the work of Dr. Apffel-Marglin in the fall of 2010 during an assigned reading in a graduate class on Indigenous education within her edited collection The Spirit of Regeneration. This opened my eyes to the incredibly useful potential of thinking about questions of (neo-)coloniality and Indigeneity anew by considering the global South and those working with the global South when thinking about and with questions of de/colonizing education. I would not meet her in person until the spring of 2012, during an invited talk at the University of British Columbia. During this talk, she was showcasing her (then recently released) book Subversive Spiritualities: How Rituals Enact the World that, as she states, was "the fruit of a lifetime of anthropological practice" (Apffel-Marglin, 2011, p. 7). Centring the pedagogical potentiality of ritual enactments, the purpose of the talk and of her book, as she states:

is an effort to articulate the nature of the kinds of beings I spoke with and gave gifts to in rituals. Here I attempt to articulate for people like myself what my new manner of practicing rituals has revealed to me about our (i.e., the modernist) way of representing reality. (Apffel-Marglin, 2011, p. 8)

Her life's work has not only focused on understanding ritual enactments, but also what ritual enactments reveal about Western modern ways-ofknowing-in-being (e.g., how Western modernity produces matter and meaning and what these in turn produce). Thus, during this talk, she spoke of "twin journeys" which are highly commensurate with Battiste's (2013a, 2013b) conception of decolonizing as deconstruction and reconstruction: a double $(\mathrm{d})$ reversal which she referred to as "reverse anthropology": 
By "reverse anthropology," I do not mean [strictly] engaging in ethnographic research on some aspect of American or European culture or society. Rather, I mean an understanding of the processes that have brought about our way of seeing reality - all of it, not just a single, particular aspect. By "our way of seeing reality," I mean what we take for granted; by "we" I mean people like me, educated in the modern educational system that by now is hegemonic and thus no longer tied to any specific region or ethnic group; by "reality" I mean things as fundamental as time, space, and nature as opposed to culture, the human person, and so forth. (Apffel-Marglin, 2011, p. 11)

In other words, this double(d) reversal entails both the literal reversal of studying those who do the studying (i.e., in order to reverse the direction of the ethnographic gaze), as well as the study of the way in which those who do the studying study (i.e., in order to reverse the way in which the ethnographic gaze is produced). It is a differential means of working towards thinking without the thing with which we cannot think without (Lather, 2007). Furthermore, this double(d) reversal is not without significance: to make rituals and the insights they provide "understandable and credible requires nothing less than a deconstruction of the modernist onto-epistemology" (Apffel-Marglin, 2011, p. 14) which render ritual Other. These include addressing a constellation of interconnected concepts enacted through practice, including the separation of Church and State in most Western modern contexts as well as the multiplicitous ways in which most non-Western, non-modern ritualized spiritual enactments are often exoticized and branded as "irrational animism" (see also Cajete, 1994, 2000; Marker, 2006). In order to make space for spirituality, she delivered a rich and robust critique of modernity, its teleology of progress, and its narrative of development by coming at modernity via multiple angles: social, political, religious, military, historical, and economic. From here, she laboured within, against, and beyond modernity by employing a reconstructive frame that interfaced quantum ontologies (to work within and against modernity) and Indigenous ways-of-knowing-in-being (to work within and beyond modernity). This framework was primarily offered as a way to think and enact the world otherwise through ritualized action.

Turning towards Dr. Apffel-Marglin's work around ritualized actions that "enact the world in concert with its humans, non-humans, and otherthan-humans" (Apffel-Marglin, 2011, p. 15) might seem uncommon for a science educator or within science education. Apffel-Marglin (2011), 
like Peat $(2002,2007)$, reminds that it is always important to remain open to knowledge outside of one's particular disciplinary pathway. She highlights the importance of being inter- or trans-disciplinary as "it has the distinct advantage of being less prey to the tacit knowledge hidden in entrenched fields and subfields of European studies and in particular in the boundaries creating such fields and subfields" (p. 14). However, there were far more spaces of potential connection and commonality than I had or could envision at the time of first encountering her work. For one, ritualized action has many connections to how IWLN are articulated:

Ritual is the medium for communicating, reciprocating, creating, and working with the other-than-humans, who daily remind the humans that the world is not for humans' exclusive use. It is the other-than-humans who make clear to the humans that human desires are not the only ones. In other words, they make clear that humans are not the masters of this world, and in turn that this world is not agency-less and voiceless, a sum of natural resources to be indefinitely mined to feed the supposedly infinite desires of human beings. (Apffel-Marglin, 2011, p. 6)

These formalized processes and protocols of and for communal (interbeing have the aim of (re)generating and the sustaining of "the iterations of the cycles of life" (p. 4l), reminding that we are not passive observers outside of the world but rather active participants within. Similarly, with respect to Indigenous science, Cajete (1994) states that:

Scientists study the tracks of subatomic particles that exist only a millionth of a second. They find the human observer influences the energy relationships and even the nature of existence of these subatomic particles. Humans do participate with everything else even at this level of natural reality. Indigenous people understood this relationship of human activity as concentric rings that extend into the spirit realm. (Cajete, 1994, p. 55)

As Cajete articulates further, "it is no accident that learning and teaching unfolded in the context of spirituality in practically every aspect of traditional American Indian [Indigenous] education" (Cajete, 1994, p. 41). If I found many productive points of resonance with Frédérique ApffelMarglin's work, and could learn much form her, it is because the degrees of separation between the spaces we, respectively, attempt to foster were far smaller than disciplinary borders presented at first. Furthermore, and of equal importance, the locations that Dr. Apffel-Marglin laboured 
within and against in order to make space for Indigenous ritualized enactments were even closer: as this involved critically inhabiting and tinkering within the spaces of and related to WMS. There was much I could and can still learn from her life's labour in this arena.

Encountering Dr. Apffel-Marglin was an unexpected turn along my own personal pathways of chance; it was an encounter that subverted the very ways in which I could be in the world, I could not (not) take up what she had offered. This (re)ignited my own interest in metaphysics, the cross-cultural space between Indigenous ways-of-knowing-in-being and quantum ontologies, as well as the importance in coming-to-know the very space that I am operating within and against to allow for a possible possibility of there being a beyond. This encounter also sparked my imagination with respect to the educational possibilities laying therein, which come to inform the later chapters of the book. It so happened that Drs. Peter Cole and Pat O'Riley were hosting a University of British Columbia summer institute in Peru the summer after which Dr. ApffelMarglin visited the University of British Columbia to give her talk. This would be located at the Sachamama Center that she ran, located in the San Martin Department of Peru and on the ancestral territories of the Kichwa-Lamista peoples. Attending this summer institute meant that there would be a possibility to engage with Dr. Apffel-Marglin in person but also a possibility of holding an expert interview. ${ }^{5}$ Sensing an opportunity that should not be missed, I had a desire to document to allow for these rich teachings to disperse: I would interview Frédérique as part of a tinkering process in which I did and would not know the end result. In turn, I sent out an invitation to do so; the same day, she replied: "I would be delighted to participate in a dialogue or interview with you and very much look forward to it" (Dr. Frédérique Apffel-Marlin, personal communication, February 14th 2013).

\section{TINKERING WITH/IN EXPERT INTERVIEW: De/Signing Research Methodology}

Wanting to recognize Dr. Frédérique Apffel-Marlin's "lifetime of anthropological practice" (Apffel-Marglin, 2011, p. 7), the methodological structure with which I sought to tinker was that of expert interview. As Bogner, Littig, and Menz (2009) state, "there is no such thing as the expert interview" (p. 6, emphasis in original). Rather, they are differential inflections on more general interview practices that predominantly 
hinge upon conceptual considerations of "what counts" as "expert", "expert knowledge", as well as what the aims and purposes of an expert interviews might be. Thus, expert interview presents itself as a methodological structure that is constituted by the ways in which the key concepts are understood and enacted. As Bogner et al. (2009) frame, a topology of expert interviews would primarily include, but would not be limited to: (a) expert interview as exploratory, to provide orientation into further inquiry; (b) expert interview as systematic retrieval, to acquire "expert knowledge" from an "expert", and; (c) expert interview as theory-generating interactive exchange.

Working towards the third type entails working within and against the second type: where notions of fact and fairy come to haunt accounts as adequately or inadequately mirroring reality (see Chapter 4), putting into question the status of and possibility of ever achieving "expert" and "expert knowledge".

Regardless of what might be myth and what is reality, the anticipated promise of rapid and unproblematic access to objective data makes expert interviews an extremely appealing option for empirical social researchers. But is the expert interview method really quite so simple and uncomplicated? If so, does this then render methodological considerations superfluous? Or are expert interviews in some ways just too tempting? Do they not - in their naïve belief in the totality of expert knowledge - harbour the danger of advocating a pre-reflexive definition of what constitutes an expert? (Bogner et al., p. 2)

In turn, the practice of methodological tinkering continues to bear importance and relevance ${ }^{6}$ : methodology is always already a space with/in which to tinker with purpose but without guarantee.

Expert interview as methodology would require tinkering with so that it was not presented as the truth, but rather a truth with which to think; a truth through which could be productively inflected or with which others could be diffracted (see Chapter 4). As such, I worked towards achieving this through three interconnected rounds of tinkering: before, during, and after. Before, I tinkered with the content of the expert interview. During, the expert interview tinkered with itself in its enactment. After, I tinker with the (re)presentation of the expert interview by pulling from insights generated through the theory-generating exchange. 


\section{Before: Tinkering with/in Expert Interview Content}

When designing the series of expert interview questions, the original intent was to create a three-part expert interview series that would differentially represent three major themes or threads that were being pulled through Dr. Apffel-Marglin's 2011 book Subversive Spiritualities. Namely, these themes were: (a) her methodology of reverse anthropology; (b) working within and against Cartesianism, and lastly; (c) working beyond Cartesianism by considering the spaces of ritualized enactments. In other words, the interviews as designed were not to repeat that which was already there, but rather tinker within the already existing narratives in Frédérique's book to connect differently, more loosely, to allow for the possibility of something else to emerge.

This began with the notion that despite the cohesive and complete appearance of the narratives within her book, like any and every text, they were and continue to be open to being tinkered with/in. ${ }^{7}$ Consisting of loosely assembled partial, situated, and relational meanings, any and every narrative is but a series of meanings that are held together by "scandalous sutures" (Derrida, 1976): what Spivak refers to as the "rage for unity" (Spivak, 1976, p. xvi). Thus, narratives are always already open to being irrupted, ruptured, and torn asunder in order to differentially sequence its frayed and fraught meanings to produce new narratives which, in turn, never achieve unity. Thus, when I was developing the questions for the interview that is featured within this chapter, I centred her work on the entangled political, economic, religious, scientific, and military practices that led to the birth and operationalization of Modernity within Western Europe. I gripped and pulled at these threads from her book Subversive Spiritualities to (re)constitute a narrative around this theme. However, in practice, this narrative was never fully achieved either, as the very practice of expert interview exceeds itself to produce something that is within and beyond the narrative framework available to it.

\section{During: Expert Interview Tinkering with/in Itself}

In practice, expert interviews come to be an enactment or practice that is and is not its research design: both the expected and the unexpected come into proximal relation to de/sign any possible expert interview methodology design. The arguments that scholars make in interviews are always situated within a real and/or imagined scene of address: what is said, what 
can be said, and how it is said is always in part produced and producible in relation to the audience to which it is intended as well as the constellation of concepts which are entangled with/in (see Chapter 4 on the prism; see also Butler, 2005; Kirby, 2011). To elaborate upon this point, Judith Butler in an interview with Vicky Kirby speaks to how possibilities of ever shifting cultural and natural norms dis/allow modes of being critical:

I think perhaps mainly in gender Trouble I overemphasize the priority of culture over nature... At the time of Gender Trouble, ... it seemed to me that there was a cultural use of 'natural' arguments to provide legitimacy for natural genders or natural heterosexuality. But that criticism did not take into account of a nature that might be, as it were, beyond the nature/cultural divide, one that is not immediately harnessed for the aims of certain kinds of cultural legitimation practices. (Butler in Kirby, 2011, p. 93$)^{8}$

Expert interviews are then a site for things to be thought anew, albeit not for the first time, within a differing web of relationships that comes to bear with differing intensities.

At the Sachamama Center in Peru, where the three interviews of roughly two hours with Frédérique occurred, each interview became an opportunity for something that was and was not her book Subversive Spiritualities: no two "readings" are ever the (self-)same (see Spivak, 1976). Dr. Apffel-Marglin and I, but her more so than I, narratively pulled at the anticipated threads differently in order to make new meanings: that which was already came to be in new relations by differentially centring how they were included or excluded, and to which degree. While the questions generated were derived from her book, this did not constrain the interviews, especially towards the end of the interviews. The expert interview alternated from being within the script, to being exceeded by the script, from being an expert interview to a dialogue in which I was also a participant: what Bogner and colleagues (2009) refer to as a "quasi-expert". This participation was nonetheless shaped by the relational elsewheres and elsewhens that exist within and beyond the interview (e.g., Frédérique's reading recommendations might be an inflection of a teacher-student relation held in other spaces). Furthermore, comfortably seated outside her modest abode within the Sachamama centre, Frédérique and I were 
also often audibly joined by other members of the ecology of relationships that shaped that place: the birds chirping, the dogs barking at one another through the nearby fence, the traditional Peruvian three-piece band practising down the road, the wind, among other things. These other-than-human beings that she refers to so often in her book Subversive Spiritualities were not simply metaphorically signified and absent, but were rather physically present and active agents in the production of the interview (Higgins \& Madden, 2019; see also Barad, 2007, 2010; Cajete, 1994, 2000).

\section{After: Tinkering with/in Expert Interview (Re)Presentation}

As the interview with Dr. Apffel-Marglin presents a partial, situated, yet rich and nuanced account of how Cartesianism is produced and producible, the interview itself invites other ways of being (re)presented within, against, and beyond Cartesianism. Accordingly, I turn to Barad (2007)'s post-Cartesian extension of diffraction as metaphor for methodology to inform how I work with Frédérique's interview.

Recall that for Barad (2007), diffraction asks us to consider where the agencies of observation begin and where they end, what is included, what is excluded, what matters, and what comes to materialize. Important to note here is that, for Barad (2007), the experimental apparatus through which any phenomena manifests is never simply a material tool or a discursive concept, but also includes multiple material and discursive agencies of observation, and extends to include each of their respective material and discursive historicities. This network of bodies of meaning and matter become the experimental apparatus through a differential enactment of the norms of bodily production. As such, these bodies do not simply interact between one another, but rather intra-act within this re(con)figured body which is the experimental apparatus. Lastly, through intra-action, materiality and discourse, the domains of ontology and epistemology, are not mutually exclusive but rather co-constitutive. Or, as Barad (2007) states "phenomena are differential patterns of mattering ('diffraction patterns') produced through complex agential intra-actions of multiple material-discursive practices or apparatuses of bodily production" (p. 140).

Diffractive methodology is thus a practice of knowing-in-being with/in the production of patterns of difference that emerge when two or more phenomena, or entangled bodies of matter-meaning, are read through 
one another (Barad, 2007). This is in stark contrast to the optical metaphor of the mirror that operationalizes the production and reproduction of sameness through representationalism. Diffractive methodology is a process of producing, and being responsive and accountable to non-negligible patterns of difference that come to matter when two or more entangled material-discursive phenomena are diffracted through one another. This requires however that "we learn to tune our analytical instruments (that is our diffractive instruments) in a way that is sufficiently attentive to the details of the phenomenon we want to understand" (p. 73) and to pay attention to the fine details that would otherwise be considered negligible with/in conventional scientific and social scientific research methods. Barad (2007) poses diffractive methodology as an engaged and enacted ethico-onto-epistemological research stance that takes seriously the entanglement of ethics, materiality, and discourse as well as the patterns of difference that emerge through their ongoing diffractive intra-action.

Here, diffractive methodology comes to inform the ways in which the ways in which Dr. Apffel-Marglin's interview is read through the multicultural education debate to produce patterns of difference that might come to inform how science education might be thought otherwise. Particularly, as diffraction is about producing differences that matter, there is an emphasis on what it means to be accountable to and for ontologically positioning science with/in Cartesianism. With/in any diffractive methodology, Barad (2007) reminds that:

We are responsible for the cuts that we help enact not because we do the choosing (neither do we escape responsibility because "we" are "chosen" by them), but because we are an agential part of the material becoming of the universe. (p. 178)

One such set of cuts enacted herein are the editorial cuts which come to produce the textual presentation of the work as expert interview. In producing the text as an articulation of (quasi-)expertise (e.g., expert as rational subject), many agential engagements have been excised. These include, but are not limited to, the now-absent presences of other-thanhumans (e.g., dogs, wind), other humans (e.g., those labouring at the Sachamama Center), human-other-than-human hybrids (e.g., Peruvian three-piece band, blaring radio), as well as moments in which speech is interrupted by thoughtful pauses, stuttering, stammering, ums and ahs. 
Both Frédérique and I have engaged in this act of narrative "cleaning" in order to produce a text that might be more cohesive, and intelligible as expert interview, to an audience to-come. ${ }^{9}$

Furthermore, the interview that follows is split into four parts. The cuts enacted here are emergent (i.e., a "choice" that emerges with/in relations that extend beyond me; see Barad, 2007), producing rich patterns of resonance and divergence when read through the multicultural science education debate. There is nonetheless a cautionary note that different cuts produce and make possible a different set of meaningmaking phenomena, this is but one possible possibility or configuration. Each cut is divided into two smaller parts: the interview with Frédérique always preceding the later diffractive analysis.

To give a quick overview of content addressed by Dr. Apffel-Marglin, the first cut, Nature/Culture, addresses how she understands this dichotomy with respect to her own field of anthropology as well as how she strategically goes about addressing it. The second cut, Descartes, Boyle, and Newton, speaks to three important figureheads not only in the development of Cartesianism, but also the ways in which they operationalize it. The third cut, The enclosure, the double-sided ledger, and the laboratory, situates Cartesianism with/in the material practices of Western Modern Europe with which it could not be disentangled and which lead to its operationalization. The fourth and final cut, The modest witness, when One Truth becomes two, and the Thirty Years' War, positions the practices of the individual within the scientific laboratory within a larger and uneasy socio-political context.

Diffracting an INTERView With Dr. Frédérique ApFFel-Marglin: ON THE (RE)Production AND Operationalization of Cartesianism and What It Produces

\section{First Cut: Dr. Frédérique Apffel-Marglin on Nature/Culture}

M. HIGGINS: Within your 2011 book Subversive Spiritualities, you speak to the multiple dichotomies (e.g., mind/body, male/female, colonizer/colonized) that you are working within and against in order to enact a double(d) reversal of anthropology (i.e., subverting the gaze as well as the concepts, categories, and constructs through which the anthropological gaze operates). Recognizing that to disrupt one binary 
is to disrupt others that are related to it (see Barad, 2010; Lather, 2007; St. Pierre, 2011a), one of the key dichotomies that you center in your work is that of Nature/Culture. Could you quickly describe how you understand Culture and Nature within this binary pairing?

F. APFFEL-MARGLIN: I have to preface what I'm going to say by saying that my understanding is totally coloured by training as an anthropologist; so what you are getting is the view that currently still, I could say, operates within anthropology. Anthropology has really made the term Culture what it is, so I should begin with that. Before anthropology defined the term Culture as we know it today during the turn from the nineteenth to twentieth century, culture was something held by a "cultured person". This usually entailed people going to the symphony, to the fine arts museum, to classical plays; that is what having culture meant. It is still used like that by people who are not reading anthropology; it is still used vernacularly like that. However, anthropology has democratized the term such that it means that everyone, anywhere in the world, has culture and that anthropologized meaning of "culture" has deeply penetrated our vernacular language. There are no people in the world that do not have culture. It is human to have culture, just as it is human to have language and to speak. Furthermore, language and culture are totally integral to one another.

Anthropology, as a discipline, takes as its object of study Culture. Studying "culture" is what anthropologists do, and the discipline has developed an understanding of Culture as an exclusive dichotomy. By exclusive dichotomy, I mean the following: that Nature is what Culture is not and Culture is what Nature is not. They determine each other negatively. It is very important to understand what that means and why it is significant. Exclusivity means that there is an absolute boundary between the two terms. While there are a plethora of dichotomies that enact a tension between two poles in which things move from one pole to the other relating to each other as a continuum, that is not the case with an exclusive dichotomy. That is a very different kettle of fish. I call the former polarities, or sometimes simply dichotomies, and the latter exclusive dichotomies. While there are exclusive dichotomies as well as plain dichotomies or polarities I reserve the term dualism to refer to exclusive dichotomies. The Nature/Culture exclusive dichotomy can be said to have dominated the field of anthropology.

M. HIGGINS: Within your book, you address the notion that the first term of any dichotomy is dominant over the latter, and that this is achieved and upheld, as you mention through a metaphysics of mutual 
exclusivity and separation. Usually this entails that the first term is constructed in opposition to the second, making the latter its abject other or its object of lack. What consequence does this bear upon Nature as well as those who are considered "natured" (i.e., rather than "cultured")? Furthermore, how has this been troubled?

F. APFFEL-MARGLIN: The troubling of the Nature/Culture dichotomy has always been important within the second wave of feminism and beyond. Feminism is an important site for this troubling because women in the Western traditions, such as Christianity and Judaism (except for the mystical traditions), have been associated with Nature (i.e., defined in opposition to Culture).

Within anthropology, this exclusive dichotomy has started to be troubled around the notion of gender, especially by a wonderful British woman anthropologist, Marylin Strathern. She does this work in her book The Gender of the Gift on her fieldwork within Melanesia. That was an early book that really is brilliant in troubling the relationship between gender, Culture, and Nature. Following this, more and more scholars in anthropology have troubled this exclusive dichotomy. Interestingly enough, in feminist approaches to anthropology, there is, from my point of view, a sharp divide between those who reject the troubling of that dualism and those who trouble it. The most well-known of those who reject the troubling of the Nature/Culture dichotomy is Sherry Ortner. Ortner maps the relations of male/female onto Nature/Culture. In her widely influential essay "Is Female to Male as Nature to Culture?", she simply takes it for granted that the Nature/Culture dualism is of the same kind as the female/male one; she assumes that there is such a division and that you can map gender on it.

This gender mapping has been crucial in exploring the CartesianBoylian-Newtonian paradigm. This is the work of Donna Haraway and, also extremely importantly, of Shapin and Schaffer on Hobbes and the air pump. So the whole Nature/Culture dualism is completely entangled with gender issues, and debates in feminism. That's why I was, from day one, deeply and personally involved.

M. HIGGINS: There is often a relationship between different dichotomies that allows the productive tinkering within one to have deconstructive effects within others.

F. APFFEL-MARGLIN: Right. 
M. HIGGINS: You've begun speaking to this here with respect to the Nature/Culture binary in relation to male/female, what other dichotomies might Nature/Culture be entangled with to produce particular bodies as "natured" and what consequences does this yield?

F. APFFEL-MARGLIN: While I talked about the case of gender, the UR [i.e., original], the basic, fundamental trope or metaphor, even if it is not seen as that, is of Nature to be controlled by Man. I deliberately use the masculine here because men developed it. They excluded women in that newly minted epistemological paradigm known as Classical Science, an exclusion that continued until the twentieth century. It really is Man, the masculine European, Western European male. So if Nature is to be controlled by Man, this also means that all other humans are closer to Nature. We talked about women, but also included within what Judith Butler has called "the abject other" are those perceived as "primitive", the "savage", and lower class. Diasporic people, Indigenous people, and other colonized people are often seen as "closer to Nature" because of a perceived inability to control themselves, their biology, or their nature. These tropes are still fully operational in the world today even if not everyone subscribes to them; they unfortunately have not disappeared. In my context of working with the Kichwa-Lamista, the Indigenous peoples in what is now the Peruvian High Amazon, they are often treated as "wild people" who have no civilization or language, amongst other lacks.

M. HIGGINS: In considering exclusive dichotomies, it is always productive to look at both sides of the binary division. If those who are perceived as "being closer to Nature" are being treated in these ways, what does that mean for those who are perceived or self-perceived as "cultured?" How is the Eurocentric, patriarchal and masculine human body, or Man, and his way of being in the world shaped and affected by this exclusive dichotomy?

F. APFFEL-MARGLIN: That's a lovely question. I'm so glad that you are asking that and I would recommend a book to you. My very good friend Ashish Nandy addresses this topic in his first book called The Intimate Enemy published in 1983. In short, it is about colonialism but it also addresses how colonialism finally hurts the colonizer as well as the colonized. When I heard your question, I immediately thought of Ashish Nandy's work. About this, I would certainly say that this way of being is one of being déchu [i.e., having lost dignity]. It is an ethical fall from grace, or a form of self-perversion.

M. HIGGINS: Paulo Freire, in Pedagogy of the Oppressed, speaks to a similar notion: to dehumanize the Other is dehumanizing in and of (it)self through a failure to recognize the humanity of the Other. 
F. APFFEL-MARGLIN: Exactly.

M. HIGGINS: This very much speaks to the notion that exclusive dichotomies are porous rather than hermetic. If we take the work of Jacques Derrida seriously, despite the prevalence and pervasiveness of this exclusive dichotomy, like other binaries, it is déjà toujours or always already deconstructing. In other words, it is never fully achieved as it is a myth or an imaginary. In your book Subversive Spritualities, you explore and leverage some examples within recent scholarship that you develop within your work that speak to the porosity of the Nature/Culture dichotomy (e.g., Cultured Nature and Natured Culture-such as cultural landscapes). Can you speak to why this is important to your work?

F. APFFEL-MARGLIN: I begin with this recent scholarship around cultural landscapes for strategic reasons. Just like the Gedanken experiments (i.e., thought experiments) in quantum physics have been empirically proven; the undoing of Nature/Culture has been enacted empirically and you cannot deny it. If you are using the language of the mainstream, it is harder to deny. Because scientists have already shown that the Amazon forest is anthropogenic [i.e., produced through and with human interaction], all I need to do is provide the data to make my point. I start with this because it is an easier way of entering into that topic. It is easier for people who are not inclined to hear your message [i.e., those who might disagree] because you are giving empirical evidence [i.e., and speaking on their terms]. Start where it is very hard to deny: empiricism. Because if I begin with more philosophical discussions around themes people do not want to hear, people close down before I've even begun. I have seen that happen in meetings and conferences.

M. HIGGINS: That's a very interesting strategy that you utilize throughout your book. On one hand, you're rejecting the universality and the privileging of WMS and its ongoing supersessionism (i.e., the double(d) process of WMS acting as the metre stick against which other ways-of-knowing-Nature are judged, as well the ways in which WMS supplants and displaces other ways-of-knowing-Nature; see Lewis \& Aikenhead, 2001). On the other hand, you are strategically using that same structure all at the same time.

F. APFFEL-MARGLIN: Right, but only when it is to my purposes. Because of my relationships to people within the mainstream, I've learned to use these arguments. But it is important for me not to stay there, and only use it as an entry point to my argument. 


\section{First Cut-Nature/Culture and the Multicultural Science Education Debate}

As Dr. Apffel-Marglin's segmented interview is diffracted with the multicultural science education debate, it comes to produce particular patterns of dynamic resonance and dissonance with one another around three key nodes: (a) Nature/Culture as mutually exclusive dichotomy; (b) problematic natural-cultural hybrids (e.g., "naturalized facts") and, (c) productively using natural-cultural hybrids.

The notion of Nature/Culture as mutually exclusive has much bearing on both the fields of anthropology and science. It is the "foundational" cut of Western modernity that puts both fields into dynamic and resonating relationality (Apffel-Marglin, 2011; Barad, 2007; Kirby, 2011; Latour, 1993, 2004). As Dr. Apffel-Marglin articulates, the mutually exclusive dichotomy between Nature and Culture can be enunciated such: "Nature is what Culture is not and Culture is what Nature is not" which is further qualified by "an absolute boundary between the two terms". As mentioned earlier within this chapter, this is deeply entangled with/in the practices of validating what one might consider valid or worthwhile (i.e., "what counts" as science) in terms of meaningmaking practices with/in Nature; within this framework, all knowledge of Nature must be made from a mutually exclusively cultural position (see Barad, 2007; Latour, 1993, 2004). Through patterns of similar differences and different similarities, as Frédérique articulates, meaning-making practices within the social sciences (such as anthropology) are similarly but differently entangled with/in the Nature/Culture exclusive dichotomy. Through the capillary circulation of scientificity, meaning-making practices within the social sciences are often (re)shaped such that knowledge of Culture must be made from a mutually exclusive cultural position (see Apffel-Marglin, 2011; Lather, 2007; St. Pierre, 2011a, 2011b).

Recall that Smith (Smith 1999/2012) posits that distance is a key organizing concept for understanding how Western modernity is enacted. She expands upon this by stating that distance becomes the enactment of the "specific spatial vocabulary of colonialism which can be assembled around three concepts: (1) the line, $(2)$ the centre, and (3) the outside" (Smith, 1999/2012, p. 55). The dividing line of mutual exclusivity is a (supposed) hermetic safeguard which masks the ways in which the outside and the inside are always already in proximal relation. Within the sciences 
as well as the social sciences, one consequence of such a mutual exclusivity is the inability to account for the ways in which Nature comes to bear upon Culture, how Culture comes to bear upon Nature, and an extreme difficulty in occupying both spaces simultaneously (Barad, 2007, 2010; Kirby, 2011; Latour, 1993, 2004). Through scientificity, the mutual exclusion of Nature and Culture translated into research practices in which cultural locations of observer and observed could be conceptualized and enacted as separate and separable: discounting the ways in which there is no outside of Culture. ${ }^{10}$

With/in the multicultural science education debate, such mutual exclusivity makes difficult even the task of engaging in the question can science (i.e., knowing nature) and justice (i.e., respecting diverse cultural knowledges) co-exist within the science education classroom? As Latour (2004) reminds us, "the notions of nature and [cultural] politics had been developed over centuries in such a way as to make any juxtaposition, any synthesis, any combination of the two terms impossible" (p. 3, emphasis in original). As explored within Chapter 3 , such a dichotomized relationship makes it such that one can ask ethical questions of science or scientific questions of ethics, but never fully arriving at something that effectively straddles and occupies both spaces simultaneously within the terms articulated by both: the production of an ethical science that is the product of both yet still retains sameness. Such is, as Spivak (1976) refers, an infinite dream of plenitude (as the concept of an ethical science would productively exceed conceptions of both ethics and science), it is an impossibility that is nonetheless worth striving for.

The goal of ethical justice-to-come within science education, or a way of knowing nature that can account for or be accountable to its cultural politics, is all the more prescient when considering what Latour (1993) refers to as particular universalism. Recall, as Latour (1993) states, one cultural location always comes to be deemed as the valid location from which to make meaning of nature: that of Man ("the masculine European, Western European male" as Frédérique states). ${ }^{11}$ It has been and continues to be articulated both within the sciences and the social sciences that the Nature/Culture binary has and upholds a Eurocentric legacy (Apffel-Marglin, 2011; Latour, 1993). As an in-between space, the same has been argued many times over that the multicultural science education debate is one that, at its very roots, operates within and against the bounds of Eurocentrism (Aikenhead \& Michell, 2011; Lewis \& Aikenhead, 2001; McKinley, 2000; Sammel, 2009); an entangled part 
of the whole that even some scientists are beginning to comment on (e.g., Mazzocchi, 2006, 2008). Lewis and Aikenhead (2001) summarize Eurocentrism as "the idea that the people, places, and events of Western European cultures are superior and a standard against which other cultures should be judged" (p. 53). Within this debate and similar others in which epistemological claims are being made across cultural contexts, it is important to consider both the relationships, and the processes of translating, between cultural spaces. This becomes all the more pressing when the West is included within this act of translations as:

Eurocentrism is the colonizer's model of the world in a very literal sense: it is not merely a set of beliefs, a bundle of beliefs. It has evolved, through time, into a finely sculpted model, a structured whole; in fact a single theory, a general framework for many smaller theories, historical, geographical, psychological, sociological, and philosophical. This supertheory is diffusionism. (Blaut, 1993, pp. 10-11)

As James Blaut (1993) explains, through this diffusionist ${ }^{12}$ model of dissemination, Eurocentric modes of thought centre themselves and propagate, all the while subjecting, assimilating, and subsuming other modes of thought (see also Battiste, 2005). "Universalism", which is one of the many faces or applied strategies of Eurocentrism, is achieved through diffusionism and the ways in which Western knowledge comes to be positioned against other systems of knowledge as the norm. Within the multicultural science education debate this relational positioning produces "the implicit curriculum message... that the only science is [W] estern science" (Hodson, 1993, p. 686, emphasis in original).

This becomes all the more complex when considering that Nature/Culture as a mutually exclusive dichotomy that is but one ontological configuration among many, as explored earlier with this chapter. As Latour (1993) reminds, the Nature/Culture binary is never fully achieved or achievable. "We Have Never Been Modern" as the eponymous title of his book proclaims. There have always been natural-cultural hybrids existing in the space(s) between Nature and Culture as the result of the ways in which Nature and Culture always already flow into one another: we are always already in a space of account-ability towards and for the ways in which ontological configurations (e.g., Nature/Culture binary) coalesce with epistemology and ethics (e.g., particular universalism). Science and science educational spaces are not exempt from 
this occurrence. While some are problematic and some offer productive possibilities, when the world is conceived of and enacted through a mutually exclusive binary, ways-of-knowing nature cannot account for or be accountable to natural-cultural hybrids.

As Dr. Frédérique Apffel-Marglin spoke, one of the greatest consequences of the particular universalism (Latour, 1993) through which science endeavours to mirror Nature from its cultural location is that some bodies are proclaimed as being "closer to Nature". Such "naturalized facts" come to be double $(\mathrm{d})$ diminishing: the ways of knowing articulated from these positions are denied validity (see Chapter 3 ), such as TEK and IWLN, as they fail to achieve the normative and "necessary" criteria of distance through which a mirroring of nature is achievable (see Chapter 4); but furthermore, it is to deny the humanity of Man's "abject other" (e.g., Indigenous peoples, women, etc.) as it relies upon a conception of Nature (i.e., ontology) as static, uniform, and unflinching such that Man's “abject other" become but uni-dimensional people (see Higgins, Wallace, \& Bazzul, 2019; McKinley, 2000, 2007).

Within other fields, responses to "naturalized facts" have been to reverse the Nature/Culture binary or to abandon Nature altogether. However, such anti-ontological stances that circulated with the social sciences with a bit more ease (e.g., "too simple" readings of Butler's [1990] Gender Trouble $)^{13}$ would not find a welcome, frequent, or widespread home within the sciences and science education despite their overlapping spaces of meaning-making (see Barad, 2000, 2011). The reversal of the resident hierarchy between Nature and Culture would not suffice or be viable to many within science education. This can be attributed to the holding and being held by knowledge of nature as separate and separable from cultural politics, often times antagonistically; they are most commonly defined and enacted through a mutually exclusive Nature/Culture dichotomy (Latour, 2004). For many scientists and science educators, the false binary choice of renouncing science to strive for ethics produces an unintelligible scientific subject (see Chapters 3 and 5). These continue to complicate questions of accounting for and being accountable to Culture (or even culture) in the process of meaning-making with Nature.

However, as Frédérique Apffel-Marglin posits within the interview, and as explored within the Chapter 3 , not all positions need to be antagonistic. There are productive intermediary positions that can operate simultaneously within and against such that it productively retains a degree 
of intelligibility and desirability. Thus, speaking to productive naturalcultural hybrids, recall that deconstruction is a two-part process which must necessarily begin with the reversal of the hierarchy but must then undo the hierarchy altogether by paying attention to the moments in which the hierarchy altogether vacillates between its constitutive terms. Dr. Apffel-Marglin's quick but incisive pointing towards her work, (see Apffel-Marglin, 2011) and that of others, with regards to anthropogenic (or cultural) landscapes opens up productive natural-cultural locations on terms that act as an invitation to dialogue rather than a dismissal. In other words, as anthropogenic landscapes are within the realm of scientific discovery, they cannot be so easily dismissed as being "antagonistic" cultural politics (e.g., in the case of the critical reversal of critiques of "naturalized facts"; e.g., Siegel, 2001), and furthermore act as an invitation to reconsider the very terms under which science operate within the very linguistic practices that science utilizes: it is a critical inhabitation.

Continuing this critical inhabitation, Dr. Apffel-Marglin begins to articulate in the following sections, the way in which the Nature/Culture mutually exclusive dichotomy (i.e., what is traditionally referred to simply as "ontology") is not something that strictly is or is not but rather in a state of ongoing becoming by highlighting processes and peoples involved in its operationalization.

\section{Second Cut: Dr. Frédérique Apffel-Marglin on Descartes, Boyle, and Newton}

M. HIGGINS: Within the Nature/Culture dichotomy, even as it always being produced anew through a continued entanglement with other binaries such as masculine/feminine, one of the common threads being pulled through is dualistic thinking. While the origin of dualistic thinking (if we can say there is one) is largely, and often, attributed to René Descartes, you extend this to also include the seventeenth century scientific revolution as well as the work of Robert Boyle and Isaac Newton. Why are these three key figures in the production of what is often referred to as a mechanical, clockwork universe, as well as dualistic thought?

F. APFFEL-MARGLIN: First, I want to preface this by saying that the new (new of course in the seventeenth century) Cartesian-BoylianNewtonian paradigm, has of course much deeper and wider historical roots. In my book, when I discuss representationalism [i.e., the epistemological and ontological web of concepts and categories enacted and 
operationalized through representation], I go all the way back to Plato and the Greek alphabet. So there are deep roots that are entangled within the Cartesian-Boylian-Newtonian paradigm, even if you stick with the birth of modernity. Not as deep as Plato, but certainly a few centuries preceding the scientific revolution. Of course this is simplifying it. Nevertheless, there is something very special and key about these three. They might not have created it whole cloth [i.e., entirely responsible for its fabrication] but it would not have had the power, particularly the persuasive power, were it not for those three because at the time it was a highly debated and contested new paradigm.

Descartes was the first philosopher of materialism. He was very systematic in his approach to establishing res cogitans [i.e., epistemology] and, by extension through separation and mutual exclusivity, res extensa [i.e., ontology]. So Descartes is writing in the early 1600s, and most of his writing is around 1620-1630 and he died in 1650. Descartes was a philosopher, so he is making a thought structure; he systematized this philosophy before Boyle comes along.

Boyle is mid seventeenth century (i.e., 1650s). He is doing his experiments with the air pump but he probably only started in the 1640s; for him the key period are the 1650s. Why is Boyle important? Boyle operationalizes Descartes. How did Boyle do this? He creates the laboratory, the modest witnesses, and a literary technology, as Shapin and Schaffer have brilliantly shown. He is important because he invents these practices that constitute the scientific experimental method. How key can you be? $\mathrm{He}$ is operationalizing Descartes' systematization of thought by making it work in action. Boyle was an actor in the creation of The President, Council, and Fellows of the Royal Society of London for Improving Natural Knowledge, also known as the Royal Society. He did this because he had to. At the time, universities were a monopoly of the church; this new knowledge had to happen outside. At the same time as the Royal Society, there was also an Italian academy, as well as l'Académie Française started by Mersenne and Descartes. However, within a few decades, the Royal Society quickly became the dominant academy of science as the king of England was funding it. To open up a new academic space outside of the church was absolutely key when it came to operationalizing Cartesian materialism.

Why Newton is so important is because he brought together Descartes and Boyle by establishing the mathematical relationship 
between Descartes' philosophy and Boyle's practice [i.e., through what is commonly referred to as Newtonian physics today]. Canonically, the age of the scientific revolution is seen as starting with Copernicus midsixteenth century with his On the Revolutions of the Heavenly Spheres that was published posthumously in 1543. Newton, with his Principia Mathematica in 1687, just clinched it. He was absolutely brilliant, and also very powerful. He was lionized. He is buried where the kings are buried in England. He was the most famous man of his time. He had advised the king and he had enormous power, power that he nurtured very carefully. He knew perfectly well, that there were certain things he could not make public, such as his engagement in practices of hermeticism [i.e., non-Cartesian Western ways-of-knowing-Nature which blended scientific practices with "magical” ones such as alchemy and astrology]. ${ }^{14}$

\section{Second Cut: Descartes, Boyle, Newton, and the Multicultural Science Education Debate}

From Dr. Apffel-Marglin's critical inhabitation of $a$ historical narrative of modernity, what we begin to see emerge here is that Cartesianism is not something that is but is rather becoming. As van Eijck and Roth (2007) remind within the context of the multicultural science education debate, it is important to consider science not as knowledge but as knowledge-processes that are highly contextualized and situated. One such consideration for Cartesianism as becoming rather than being is to refuse its frequent positioning as naturalized within an ahistorical present (see Spivak, 1999). However, even if we trace its historicity, it cannot simply be referred to as knowledge originating from and obtained by René Descartes that, as the truth, mirrors metaphysics. Rather, it is a knowledge-process that is without an origin (e.g., Plato): its meaning and matter are always deferred and differing such that it forms an ongoing citational chain (see Barad, 2007, 2010; Derrida, 1976). Cartesianism, as Dr. Apffel-Marglin explains, is not created "whole cloth" by René Descartes, nor by Thomas Boyle, or Isaac Newton: Cartesianism is something that precedes, lives alongside, and outlives all three through its circulation and differential enactments across a multiplicity of spaces. Nonetheless, these three do come to be key actors in the operationalization of Cartesianism such that it is widespread, commonplace, and "common sense"; something one has and by which one is had (see Barad, 2007; Higgins, 2014). 
Diffracting Frédérique's account of Descartes, Boyle, and Newton with and through the multicultural science education debate again reinforces the notion that the Nature/Culture mutually exclusive dichotomy is but a configuration among many and that it is an onto-epistemological enactment that we are responsible for; even if, as Barad (2007) states, we choose and are chosen by such configurations (see also Butler, 2005). However, what significantly begins to resonate with this vignette is that Cartesianism, when considered through distributed agency (Barad, 2007), can be considered as a "regime of truth" (Foucault, 1977, 1979). In other words, through their respective metaphysical framework, laboratory practice, and mathematics, Descartes, Boyle, and Newton implicitly enact theory-practices that implicitly come to support one another. As Foucault (1979) explains, "truth' is linked in a circular relation with systems of power which produce and sustain it, and to effects of power which it induces and which extend it" (p. 47). The example at the beginning of this chapter could be stated as a singular application of such a regime of truth: Cobern and Loving (2008), in their argument for (re)considering and supporting an epistemology of "epistemic realism", pivot and side-step to "ontology" (read: singular; i.e., Cartesianism) without being accountable to or for the ways in which the two share a co-constitutive onto-epistemic relationship. This is often the case when and where it comes to the defence of WMS as the way of knowing nature: these diverse knowledge claims which come to reinforce WMS almost always operate through the differing similarity through an implicit assumption that Cartesianism is the (only) ontology. It is no surprise, as Dr. Apffel-Marglin continues to expand upon this, that Cartesianism comes to be (re)presented as "common sense" (as Cobern \& Loving (2008) define it), holding the ahistorical appearance of stability, neutrality, and normality.

Furthermore, as indicated here and expanded upon within the next section, knowledge and power share a co-constitutive relationship and important role in the dispersal of such knowledge-practices (Foucault, 1977, 1979). For example, the earlier footnote regarding Newton's dual positioning with respect to modern science and hermeticism reveals Newton to having, and being had, by power. He is being produced as a scientific subject that simultaneously upholds and is upheld by systems of power. ${ }^{15}$ However, as discussed in the following section, such a dispersal of knowledge-practices comes to bear at a larger scale when considering 
the technologies which operationalize this way of knowing-in-being (e.g., the enclosure, the double-sided ledger, and the laboratory).

\section{Third Cut: Dr. Frédérique Apffel-Marglin on the Enclosure, the Double-Sided Ledger, and the Laboratory}

M. HIGGINS: While we are on the subject, within your book, you make clear that "the scientific revolution was not the result of decades of discoveries, but was in the making for centuries" (Apffel-Marglin, 2011, p. 33). While ideas and ways-of-thinking, like the CartesianBoylian-Newtonian framework, are always being (re)generated, those that "stick" (and stick around) are those that are operationalized and become embedded within the matrix of power/knowledge. It is important to speak of Descartes, Boyle, and Newton when tracing or retracing the production of the Nature/Culture exclusive dichotomy, as they were key players in making operational this dualism. However, this is not to say that the scientific revolution to which Nature/Culture is often attributed origin was not entangled with and in the social, political, religious, economic and other events, tensions, and forces that were happening at the time as well as the time which preceded it. Could you give a thumbnail account of the state of the European subject historically around and preceding the "tipping point" of modernity [i.e., the scientific revolution]?

F. APFFEL-MARGLIN: There's two ways I can answer that question. I could answer it in terms of the forces that killed hylozoism [i.e., a Western European relational way-of-knowing-in-being of the time premised around the notion that all matter is in some sense alive; shares a relation with hermeticism] and made what Descartes or Boyle called the molecular or atomic model of the world, and humanistic/materialistic dualism the dominant and winning view.

Another way to answer this question is to go historical and speak to the history of the fall of the manorial system, sometimes called the feudal system, and all the conflicts that emerge. I have to preface this by saying that I owe a serious intellectual debt to my ex-husband Stephen Marglin's work, as he's done a huge amount of historical work on the birth of capitalism. Drawing from literature on economic anthropology, historical economics, and such works, I have come to the view that the enclosure movement is associated with the birth of Cartesian dualism. What I argue is that it is that economic context of the emergence of mercantilism, which isn't yet capitalism, but rather proto-capitalism. It is a proto-market 
economy that comes to replace the manorial system that begins with the enclosure of the commons. The enclosing of the commons started in Western Europe, continued through colonialization, and now persists through globalization. It is incredibly relevant when you're dealing with Indigenous peoples, places, and protocols as this enclosure movement has continued. The enclosure of the commons is for me the key thing that gives the social, political, and religious context that gives credit and credence to Descartes', Boyle's and, Newton's intellectual work and makes it stick.

M. HIGGINS: As you state in your book Subversive Spiritualities, understanding the enclosure movement and the encloser's advantage are important in setting the stage for and are entangled within the operationalization of the Nature/Culture dichotomy. Could you speak more to this movement and its consequences?

F. APFFEL-MARGLIN: At the time of the enclosure movement, there was a lot of conflict. It was a time of peasant wars in France and in England. There was tremendous social and political conflict. However, the enclosure movement was simply a power play.

This plays out similarly today: governments in the global South are currently signing the Free Trade agreement with the United States in which the small print says that you have to make land available to businesses, that land being the commons for Indigenous peoples. Because Indigenous peoples don't have title to it, the governments can say "no, we're giving it to the oil companies, the mining companies, the timbering companies, the agri-chemical companies, etc.". That is currently what is going on, and it is going on everywhere in the global South.

This is what happened, first in England, France, and a few other countries in Western Europe. The rich powerful merchants simply bullied others to get their way through the local courts. Because they had money and connections, they could make it stick. They gained title to the land, and then they actually put up a fence: that's what enclosure means. So you put a fence, and say: "this is mine". Then you use the land as you see fit. At the beginning, it was because the price of wool cloth went up and the world was trading wool cloth, so they wanted to get into that trade by raising and pasturing sheep. So they simply bullied everybody with the support of the aristocracy because many merchants were aristocrats. They made it stick legally through the courts but also through direct violence. 
M. HIGGINS: One of the things I appreciate in this discussion and in your book is that the enclosure is not only a figurative or epistemological form of separation but rather or also one that is literal and material. Part of this comes into play in your exploration the enclosure as an enactment through the calculation of the encloser's advantage in which you make clear that the calculation not only exerts power following its enactment, but also through its enactment; the calculation itself and that which is entangled with/in it is important.

F. APFFEL-MARGLIN: This is directly related to the beginning of banks. I've fallen by chance on this while exploring the history of mathematics. In my discussion of the whole history of mathematics within Subversive Spritualities, an important moment is when one becomes a real number. One is what you use for counting; when one becomes a number, it creates a new category, that of magnitude.

The first banks emerged in the great merchant cities of Italy. The Latin word ratio, while I didn't do the philology [i.e., the study of language in written historical sources located between history and linguistics] of it, I understand it to mean double-entry book-keeping from its use at the time. It also bears a relationship to rationality. Ratio becomes rationality: that's the way it is born. The double-entry ratio-based calculation [e.g., quantifiable equivalencies], that's what makes rationality possible.

To calculate one's advantage, you have to remove yourself. Remove yourself from the land and the community. The people and the land are no longer one thing, belonging to each other sharing and living together. If you go into Indigenous communities, people usually do not calculate like that, even among small farmers in India. That's where I first encountered it. In the Indigenous communities here (Peruvian High Amazon), it's glaring: no one calculates in these ways. You do things to live and to regenerate life.

It goes together with my argument about the Burning Times when they exterminated hylozoism, hermeticism, alchemy, and various other ways-of-knowing and -being. The peasants, the so-called witches, and the so-called magicians were very close with each other and constantly sharing knowledge through contact with each other. Therefore, calculating the encloser's advantage has political, economic, social, and spiritual consequences. They are all entangled.

The mutually exclusive Nature/Culture dichotomy has its birth in removing the people from the land, and using the land as an economic asset. Land becomes a thing, an object on or through which, depending 
what you do with it, one generates an economic profit based on and derived through calculations of an advantage accruing to a single (male) owner and along with it excluding the other members of the land, the non-humans, the other humans in the community and the other-thanhumans, namely the earth beings. Advantage was the term that they used at the time. This is the beginning of the end.

M. HIGGINS: Could you speak further to the consequences of the enclosure movement for those who were unwillingly entangled? What did this mean for those who might not have had the privilege of being an encloser?

F. APFFEL-MARGLIN: The herbalists, like Indigenous peoples and their relationship to Land, depended on being able to live in the forest and knowing the forest very well, its animals and plants, in order to know how to heal people. However, once the commons were enclosed, they were no longer allowed access. They could not continue their practice. The church backed the powerful by calling the commoner women witches, and by calling them heretics. At the end of the fifteenth century, in 1484, the Pope in Rome declared witches to be heretics. If they could be proven to be witches, they were to be burned. This was the Burning Times. Witches, however, had always existed, why declare them heretics at the end of the fifteenth century when they had always been around? The short answer is that they were no longer tolerated. I argue that the main reason why the inquisition set on them at that particular time in history is to be correlated with the enclosure movement.

At the time the process of enclosing the commons was going on hylozoist experimenters and Cartesian-Boylian experimenters were having debates. When discussing enclosures, you had those who were criticizing and those who were defending this practice. Critics and defenders could be from the same class; it depended on one's politics. But not unlike today, those who defended the enclosure tended to be landowners: wealthy merchants and aristocrats. While there was this tendency, you cannot say 'always' here because people did not always act according to their class.

It is not unlike what's going on today in the Global South in general. Recently, in Bagua, Peru, a similar debate was public. It was amazing to see that everyone who was criticizing the enclosure of land professed that everyone has a right to the commons. That is the meaning of a commons, belonging to everyone. The vulnerable, the old, the widows, those who are unlucky, and etc. are assured of their daily bread; they 
can live because they have access to the commons. The calculation of the encloser's advantage begins with the enclosure of land and thereby making land an exclusive property of the encloser.

I'm now writing for an encyclopedia of Hinduism on how food was seen in pre-colonial times in India. Everyone has a right to life by virtue of being born: that is how the polity [i.e., local government] was organized, and how people behaved. If you are alive, you deserve to eat. What emerges through the enclosure of the commons is that you eat only if you work earning wages with which to purchase food which implies the associated need of creating labour as a commodity. You have to sell your labour because it is the only way you can access food. Selling one's labour requires a previous transformation which consists in owning your individual body whose labour power is something that you can sell because you are its exclusive owner. Before the enclosure movement, and in today's Indigenous and small peasant societies, your labour is not something for which you get paid. Instead, your neighbours and your relatives get together everyday and work on your land and tomorrow you're going to work on their land-that kind of principle. You can extend it to other and bigger things, but that is how people do things; labour is not a commodity or something you sell.

M. HIGGINS: The creation of the body as labour speaks to the operation of what Karen Barad (2007) refers to as a "metaphysics of individualism". In other words, a body, be it human, other-than-human, or more-than-human that is separate and separable. This, as you state, disrupts relationships of community between human, non-human and other-than-human. Could you elaborate more on the notion of closure and boundedness of the human body and how it ties into this separation and separability?

F. APFFEL-MARGLIN: The non-porous body bounded by the skin is necessary for the emergence of labour as a commodity because you have to own your body, its power and its force, in order to sell it. The body as a biological bounded separate entity that you own so that you can sell it implies a capitalist market economy. Labour is, according to Karl Polanyi, one of the three forces of production [i.e., land, labour, and capital], without which you would not have capitalism.

If you insist on the biological boundedness of bodies and you teach that to kids, you implicitly reproduce the capitalist mode of production. This entails a devalorizing of the commons and what I call the cosmocentric economy, the exchange of gifts within the human, non-human and other-than-human communities and everything that these represent. 
Accordingly, it is a statement that Indigenous and rural peasant people are backwards and superstitious, while simultaneously opening a wide space for the entrance of a profit-motivated market economy. This closes the door to non-modern ways of life in which the commons are central. Not only commons as land but its web of interconnected commons: food as commons (i.e., one person starves, everyone starves; one person eats, everybody eats), water as commons, air as commons, knowledge as a commons.

M.HIGGINS: In your book, you speak of this with respect to the spirit of the gift and communal labour. It is not the measuring or quantification of labour that is important but rather it is the act of coming together and working towards common goals that is important.

F. APFFEL-MARGLIN: Exactly, and you can extend that. The labour is not only to cultivate the neighbour's field or your relative's field, but it is also for festivals. In medieval Europe, all the cathedrals were built that way. All the non-modern great works, like the pyramids in Egypt and in meso-America, they were built in that way. It was not paid labour because there was no labour as a commodity; you do it for the community, not only of humans but also for the non-humans and other-than-humans.

Accordingly, there are important ties between labour as commodity and land as commodity. Through the enclosure of land, land emerges as a commodity. Becoming private property, you can buy and sell land because it belongs to somebody. It is the same thing with labour as a commodity. It makes the body a form of property. You own your body; and because you own your body, you can sell your labour power on the market.

It's a profound transformation. However, it took a long time to change the habits of people, to make people develop the habits necessary to create labour as a commodity within these new norms. Nonetheless, because labour as a commodity is an abstraction, this profoundly transformed the sense of what a person is and can be.

Schooling plays an important and ongoing role with this. It was and is through schooling, especially early nineteenth century and the end of the eighteenth century during the period when schooling became obligatory, that you learn the disciplines necessary to sell your labour power. In many Indigenous communities, you typically did not or do not do this. The transitions that occurred during the modernization of Western Europe continue to be relevant today, even if these transitions happened in other parts of the world at another time. 
M.HIGGINS: This is certainly a double(d) form of disciplining bodies within schools. Students are not only learning the disciplines (e.g., sciences, arts), but also learning as a form of discipline in and of itself.

F. APFFEL-MARGLIN: Of course, through many bodily cues: the bells which reinforce punctuality and a disciplining of time, bodies sitting at a desk in a row of desks for so many hours engaged in mental focus, all of these things and more.

M.HIGGINS: Foucault's Discipline and Punish does a terrific job of unpacking the normative organization of bodies within systems of schooling and the modernist values at play there.

Directly related to this is the question of Boyle's laboratory. While Descartes is often attributed dualistic thought (i.e., cogito ergo sum), you state that it was Boyle who operationalized it through his "technologies" of the scientific laboratory. What did these entail and how did this work towards the operationalization of the Nature/Culture binary?

F. APFFEL-MARGLIN: I have to preface this by stating that Boyle used to be an alchemist, which is a form of hylozoism. But, in the transition to the laboratory, he shifted from a hylozoist practice to a dualist one. The work of Elizabeth Potter is key here because she shows that he was a big landowner. He was politically motivated by the possibility of losing his land. That's the beauty of this kind of work. It shows that the scientific method and the experimental scientific method had everything to do with politics, economics, and religions of the time and place.

Getting back to your question, this is pure Shapin and Schaffer and the work they do in their book Leviathan and the Air Pump. In their work, they identify three technologies which I mentioned earlier. One was the creation of the laboratory. Prior to the scientific revolution, the hylozoist or hermeticist (known under the more general term of "occult philosopher") worked in private in a secret cabinet. There he did all sorts of alchemical experiments, as well as other kinds of things. He would use a variety of instruments to conduct experimentations. However, a crucial shift was when the lab became a public space. Why did it have to be a public space? For several reasons; one of which being that by making it a public space you are stating that you are not an occult philosopher. Making the laboratory a public space is equivalent to declaring that "I'm not an Occult Philosopher". While it was still a choice to be a hylozoist at the time since there were active debates at the time between hylozoists 
and mechanicists, the hylozoists were still being persecuted by the inquisitions of both Protestants and Catholics. Second, it had to be public in order to establish what Shapin and Schaffer call the social technology.

This second technology, the social technology, was utilized to establish the facts, which was called the "matter of fact" or the scientific fact, within the laboratory. The model for this system being the court, ${ }^{16}$ and the court being a system of witnesses, facts would be established through witnessing. To do this, you had to have witnesses to the experiment and have a discussion about what was witnessed. Only when there was a consensus of what they had seen could the matter of fact be established. To achieve this what was needed was a public space with several witnesses.

Key to the act of witnessing is what Boyle called the "modest witness". The modesty, what did it entail or mean? It meant that the witnesses had to be reliable people who would not let their personal preferences, personal desires, personal biases influence what they saw, and what they would say they saw. That is what excluded women because the belief at the time was that the modesty of a woman was of the body, that she did not have modesty of the mind.

The third technology is a literary technology. It was for those who could not be there, present to witness the experiment whether they lived in some other country or simply could not come. They had to develop a technology that could describe what happened without interjecting any opinion. This literary technology came to be known as the objective style of writing. "It has happened", that type of linguistic construction. It was so that those who were not present could have what came to be called a precise and objective account of what happened. The remaining technologies had to do with the distribution of these texts. So those are the three technologies.

\section{Third Cut: The Enclosure, the Double-Sided Ledger, the Laboratory, and the Multicultural Science Education Debate}

A notion that persistently resonates as the multicultural science education debate is diffracted with this segmented cut of Dr. Apffel-Marglin's interview is that, as Aikenhead (2006) reminds us, "natural philosophy [is] the handmaiden of technology" (p. 11). Scientific technologies are never simply the applied form of science knowledge: they always come to coconstitute one another. Further, technologies are never simply neutral nor 
passive cultural surfaces, they are both products and producers of cultural values.

Expanding upon the lines of thinking followed within the second cut, not only is the operationalization of Cartesianism an enactment that is distributed among a series of agents, but it is also distributed among a series of increasingly "common" technologies which precede, live alongside, and succeed Boyle, Netwon, and Descartes. If we think diffractively with technologies (and not only scientific ones concerned with generating or applying knowledge about nature) then: Nature, metaphysics, as well as how they are understood and enacted through knowledge-practices always come to bear. Social, political, and economic technologies come to be ontological enactments; as well as epistemic ones in which social, political, and economic dimensions come to coalesce without ever fully achieving sameness (see Barad, 2007; Kirby, 2011). The technologies of the enclosure, the double-sided ledger, as well as the laboratory are all supported by particular ways-of-knowing-nature such that they are produced by and (re)produce a "metaphysics of individualism" (Barad, 2007): knowing-in-being premised upon matter and meaning being separable and individuated through mutual exclusivity. Such ontological cuts are never neutral, but are always already entangled with culture and ethics; even if the enactment is (re)producing epistemic, ontological, and ethical separation, it is nonetheless placed within a set of relations, even if the relationships go unaccounted for and unaccountable within said framework.

This includes, of particular significance to the multicultural science education debate, the very practices of the laboratory. ${ }^{17}$ The practices of knowing nature within WMS are often premised upon scientists operating from a culturally unbiased, neutral, and detached position (see Aikenhead \& Michell, 2011; Aikenhead \& Ogawa, 2007; Siegel, 2001), and are supported by social and literary technologies which assist in the production of such (e.g., the laboratory as public space, objective writing style, and modest witness). However, as Dr. Frédérique Apffel-Marglin states, "the scientific method had everything to do with politics, economics, and religions of the time and place". As mentioned herein, Thomas Boyle, a key figure in the development of the laboratory as a technology, was also a landowner. In turn, his politics outside the laboratory came to shape his politics inside the laboratory even if the laboratory were to be promoted as an apolitical space; he would implicitly and explicitly be bringing in 
and enacting the technologies of the double-sided ledger and the enclosure within the laboratory whether they could be or were accounted for. Note that one should not confuse the practices of the laboratory with those of the enclosure or the double-sided ledger, but rather, thinking diffractively (or even with prismatic dispersal) speaks to the ways in which these practices intra-act with one another in non-negligible and dialogical manners: creating something that is not dialectically mirroring one or the other through sameness but creating a complex hybrid practice whose historical and agential constitution often goes unaccounted for.

Recall that, as mentioned earlier within the chapter, attempting to make sense of and act with TEK and/or IWLN through a EurocentricCartesian framework almost always results in the perception of these knowledge-practices as lesser alternatives to WMS. Thinking with Frédérique here expands upon that notion: a Eurocentric-Cartesianism framework does not only come to devalue other ways-of-knowing-nature. When considering its operationalization as well as its entangled practices, it also comes to disrupt their (re)generation. Dr. Apffel-Marglin makes the case above that the entangled practices of the enclosure and the double-sided ledger come to produce destabilizing patterns within TEK systems within Western Europe at the turn of modernity, patterns which would and do continue through the imperial cum capitalist project of (neo-)colonialism. ${ }^{18}$ First, through the practice of the double-sided ledger, land can be assessed as through a reductionistic logics of equivalence and sameness through quantifiability. In the short physical space between one side of the ledger and the other, the human, other-thanhuman, and more-than-human ecology of relationships is reduced to both a spatial area and a fiscal value which are given the status of equivalency: a veritable trick of smoke and mirrors. Secondly, by making the commons private through the enclosure, the unaccounted for relationships which shape entire lived knowledge systems are disrupted. Knowledge holders no longer have the same type of access to the landscapes with and from which they learn (see Cajete, 1994); furthermore, the relational and ethical knowledge-practices through which these ecologies are (re)generated are not sustained. Lastly, when the enclosure and the double-sided ledger are metaphorically inflected through human bodies that live(d) in and with the commons, they too become commodities. The biological boundedness of the human body and the economic logics of sameness (re)shape labour as commodity rather than something that one gives and receives unequally but rather equitably within a reciprocal 
gift-based economy: "You own your body; and because you own your body, you can sell your labour power on the market". As these values came to permeate the social, political, and economic facets of Western modern life, it "profoundly transformed the sense of what a person is and can be" by (re)shaping the norms of subjectification.

While these social, cultural, political, and economic values slip their way into scientific practice unnoticed and unnoticeably due to its framings as apolitical, the apolitical stance of the modest witness is also produced by the social, cultural, and political climate of the time, as explored within the next section.

\section{Fourth Cut: Dr. Frédérique Apffel-Marglin on the Modest Witness, When One Truth Becomes Two, and the Thirty Years' War}

M.HIGGINS: Regarding the modest witness and the norms that shape who can be a witness, you've mentioned that women were excluded on the basis of the gendered understandings of modesty at the time. Were there other people who were excluded and on what basis?

F. APFFEL-MARGLIN: Yes, there are absolutely others. In the laboratory's beginning, to be in the lab, you had to be independently wealthy to participate. This was for two reasons. First, you had to be wealthy because it was personally expensive: you had to have the time, as well as have education that entailed knowing mathematics and a few other things. Only the wealthy people could be educated; they were all men. As such, the "modest witness" excludes not only all women but also a lot of men such as the lower classes and the uneducated ones.

Secondly, it was systematically expensive. This was because the university was church business. One of the fundamental characteristics of the lab, as Boyle set it up, was that within that space it was absolutely forbidden to talk about religion and politics. Now why do you think that was? Why do you think he made that rule if we're talking about the seventeenth century and what was going on in the seventeenth century?

M.HIGGINS: There were still witch-hunts going on, right? There would be politico-religious consequences for those who might be hylozoists and hermeticists, which go far beyond attempting to be "modest" in one's assumptions and biases, correct?

F. APFFEL-MARGLIN: Yes, and what else? 
M. HIGGINS: There also would have been the politics of land ownership I gather, but I'm guessing that there is something even more critical than this.

F. APFFEL-MARGLIN: Wars of religion. They are also key in understanding the birth and operationalization of the Boyle-NewtonianCartesian framework. It started with the Reformation in 1510 with Martin Luther. Protestants immediately had a following amongst the merchant and certain aristocratic classes, and even among some royal families. It divided countries between regions that were Protestant and regions that were Catholic.

The Catholic Church is a centralized church which has a pyramidal hierarchy with the Pope at the top. Because of its pyramidal and international organization, as well as its domination of education at all levels, they could decide what people should and could think and read, as well as what they should not think or read. It still exists today, the means through which a dominant curriculum was established and monopolized: what they call Librorum Prohibitum. It tells you what is what, what is true, what is superstitious, and what is false. They also have the power of excommunication, which was very powerful at the time. It is not like today.

The problem then and there was the following. The reformation spread very quickly. Protestants stated "we have the truth; the Catholics are mistaken; what they do is magic". In Western Europe, the One Truth became two. Both Catholics and Protestants each said they had the One Truth. It was explosive. Indeed, it created mayhem. They killed each other with gusto, brutality, and horror.

In the early seventeenth century, they assassinated Henri IV, King of France [not to be confused with Henry IV, king of England from 1399 to 1413]. He was Protestant but to be king he had to be Catholic. That is what he meant by his famous line: "la France vaut bien une messe". It was well worth going to mass in order to be the king of France. There were 8 bloody civil wars in the sixteenth century, in the 1500s, so he made a very famous law: the Édit de Nantes in 1598 [the Edict of Nantes]. It was a very modest proposal to live together without killing each other. In regions in which the majority was Protestant, the Catholic had the right to have their religion albeit not display it publicly. In regions in which the majority was Catholic, it was the reverse. They had the right to practice, but not to display; not rub it in the face of the other. While it was a minimalistic accommodation, it worked. However, there were 10 
assassination attempts against Henry IV, and finally the last one worked: he was killed in 1610. His second successor, not the next king but the king after that, Louis XIV eventually threw all the Protestants, known as "huguenots", out of France.

This is a thumbnail outline of something that is, in my opinion, fundamental to understanding the birth of modernity in the West. This is in relation to how it related to Christianity, and the One Truth; as well as its shift to having, all of a sudden, two One Truths. But there can't be two One Truths, right?

What Boyle did with the laboratory, why it worked, and why it became the prevalent approach in that day and age by accruing the most political and economic power, was because it solved something that was unsolvable. This unsolvable issue was the One Truth becoming two truths with each religious organization saying: "we have the One Truth and you are heretics". When echoed, this led to killing each other. When Boyle created the lab and stated that you could not talk about religion within that space, he created the germ or seed of secularization. The lab, and with it all of Nature, became a neutral domain outside of religio-political domains, a new neutral domain upon which the lost certainty to which Europe was addicted could be safely reconstructed.

The lab was the first neutral, or in other words, secular place in Europe. Before that, you could not be a secular person; it did not exist in Western Europe or anywhere else. That is the birth of religion as a category. Before this, spirituality was interwoven into the fabric of life: it was one seamless way of life. That is the way it was. So this was the first time that you had a space where you could not talk about what pervades life or has pervaded life for everyone.

Speaking of religion was simply forbidden. And why was it forbidden? It was very simple: if you talked about religion, you might kill each other. The reason why politics could not be discussed within the laboratory is because politics and religion went hand in hand. They could not be separated. The Protestant had their political leaders and the Catholics had the king. Politics and religion were one and the same.

What Boyle was creating was a separation for a very pragmatic reason. He was creating a space where you could argue in a friendly, nonconflicting, and accordingly non-lethal way about other matters. What are the other matters? What you have witnessed within the laboratory. Because the model is the court, there is one more reason why he used the judiciary model of argument. Within the laboratory, everyone had a 
right to participate if you did not touch upon topics of politics and/or religion. Because they had a right to opine, the consensus that emerged around what happened through experimentation would be strong.

At the time, his greatest competitor, Thomas Hobbes was arguing for a new model in which people would not disagree. This was seen as dogmatic. Boyle was trying to get away from the dogmatism of the Catholic Church and the Protestants. He was attempting to get away from the idea that people have no choice because of dogmatic statements "this is how it is" whether Protestant or Catholic. He was moving away from that while strengthening truth claims through encouraging disagreement within very strict boundaries. When you allow people to disagree within bounds, the consensus is strong without being dogmatic. It became a very powerful solution that addressed and solved the issues of the times within the privileged space of the laboratory.

M. HIGGINS: If I understand this correctly, this would also have consequences for what was intended by modesty at the time. As you speak to in your book Subversive Spiritualities, secular modesty put forward by Boyle in the laboratory is very different than the religious modesty put forth by the Christian church before it. Religious modesty entailed not being a spiritual usurper, not having too many belongings in this world, or to be a martyr of sorts. Secular modesty, in contrast, largely meant being "modest" in one's beliefs by abstaining from talking about religion or politics. However, if the secular modest person also had to be wealthy as an entry point to participation, this circumvents ethical questionings of wealth altogether.

F. APFFEL-MARGLIN: You simply did not discuss those things in the lab.

M. HIGGINS: The process of supersessionism, or the ways in which WMS supersedes Indigenous and other ways-of-knowing-Nature, could be said to have an almost religious quality to it. However, this is not because of ties to the church, but as you identify, this largely has to do with what you identify as an addiction to certainty and objectvity/subjectivity as one of the ways in which the Nature/Culture binary plays out. Could you elaborate upon this process?

F. APFFEL-MARGLIN: As I mentioned earlier, the social-politicalreligious landscape of Western Europe in the seventeenth century was one of raging religious wars and the Burning Times which came to an end in the second half of the seventeenth century. As I like to say, irreverently, Europe was addicted to the One Truth because it had lived with it for 15 centuries or more with Christianity. Europe required certainty to restore law and order, as Stephen Toulmin has shown in his book Cosmopolis. A new neutral—and very separate—domain of inquiry, 
Nature, and with it a new epistemology, were required. That new epistemology needed to have its life in a new neutral space, that of the laboratory. While there are exceptions, this is still true today. The One Truth is an addiction.

So in order to resolve the impossibility of two One Truths in Europe, a circumscribed space that was neutral vis-à-vis both the Protestants and the Catholics was invented. Within this space, a certainty that was not religious was created. It was desperately needed and it was a very circumscribed space. Hence, the laboratory took off.

At the time, religious wars were international. The Thirty Years' War, which lasted from 1618 to 1648 , was the internationalization of what I described in France earlier. Similar things were also happening in England and Germany. The Treaty of Westphalia was signed to bring an end to the Thirty Years' War. This process creates, invents, and necessitates the nation state.

Immediately, the nation state needed a science to function and to govern. Here, I draw from the work of James Scott and his book Thinking like a State addressing why the nation state cannot function without science. I cannot simplify that story for you, but I will attempt to give a quick and partial view. In a nutshell, the state has to manage two things. First, it has to manage conflict, which was religion-based. Secondly, the state had to generate revenue. To get revenue, you have to systematize and quantify. It is like what the encloser would do when calculating his advantage but now this logic is playing out at the national level. This, of course, is a partial view.

M. HIGGINS: This addiction to certainty certainly has persisted strongly within Western modern(ist) traditions-to which it has had its own internal challenges (e.g., the crisis of representation in the 1990's). However, it is not uniquely internal to Western traditions as the addiction to certainty is being exported and culturally transposed...

F. APFFEL-MARGLIN: Through the hegemony of modern education worldwide!

M. HIGGINS: In your book Subversive Spiritualities, you speak to the addiction to certainty and how WMS (i.e., agricultural models in particular) supersedes Indigenous local, longstanding, and intergenerational models due to the ways in which it is framed or enacted as holding a high degree of certainty. Could you speak to the ways in which certainty was and continues to be constructed? 
F. APFFEL-MARGLIN: Here is the way I've come to see it. The founding myth of Modern science is the trial of Galileo vs. the Catholic Church. Here you have rationality and belief. Of course, this myth was carried forward into and leads to the progressive secularization of society through the laboratory later through the Nation State. This created certainty on a whole new basis: the experimental method, deduction, rationality, logical thinking, objective writing, and all; the whole package.

What I see when I take that long view is that religious certainty has been transposed into a new key, to use a musical metaphor. Scientific certainty is the same thing but, of course, the new key is crucially different. The key is crucially different but the tune is the same. It is similar in its absoluteness in the sense that its method is the only valid one, its claim to the One Truth: Science gives you the One Truth but in a new language and on a new basis. In the process it had to disenchant nature, as Weber put it, and with that move transmute all other ways of knowing-being as "prescientific" in need of progress. Because Western Europe was addicted to certainty and the One Truth, it had recreated it in a new secular key with Modern science.

That is why the "universal" given-ness of Nature is so pernicious. Scientific rational superiority became a deliberate part of an educational campaign to inculcate in the European youth, and to shape perceptions about those who Europe colonized. Colonialism is justified through statements such as "this is right because we are enlightening these unenlightened people; we are bringing them not just civilization, we are bringing them knowledge, True knowledge". Of course, such is predicated on seeing Nature as universal.

As Karen Barad says, you can never separate or disentangle the discursive from the material. This disentanglement, however, is key to the formulation of certainty. The issue for me is that it is very difficult to have people understand this because it goes against the grain of everything they likely have been taught.

M. HIGGINS: Dualistic thought is not something that can simply be turned on or off.

F. APFFEL-MARGLIN: Exactly. You can say it conceptually in all its implications. However, what happens in practice is otherwise and extremely difficult. 
M. HIGGINS: Which dualisms are we reproducing as we try to work against others?

F. APFFEL-MARGLIN: It is always a process; an unfinished work.

\section{Fourth Cut: The Modest Witness, When One Truth Becomes Two, the Thirty Years' War, and the Multicultural Science Education Debate}

Reading the insights provided by Dr. Apffel-Marglin in this this vignette through those of the multicultural science education debate begins to reveal the ways in which the apolitical stance of cultural quasi-neutrality explored within chapter is a process which comes to mask the flow of common-place cultural power and politics into the laboratory, but also the ways in which this stance is produced by the social, economic, and political forces of the time. What might appear as an individualistic choice here could be (re)thought as having and being had by common sense.

This stance, as Frédérique enunciates it, is one of being a modest witness. The modest witness, as one of the multiple technologies that come to constitute laboratory practice requires that the individual whom is witnessing be educated, as well as "modest of mind". Here, we come to see the Foucaultian circularity of knowledge comes to rear its head again. First, recall that the Nature/Culture exclusive dichotomy, with/in which WMS is entangled, comes to negatively position Man's (human) Other as "closer to nature". Accordingly, women, racialized bodies, Indigenous peoples, amongst others, as being perceived as possessing "modesty of the body" rather than that of the mind, ${ }^{19}$ were generally not included in the very processes which would implicitly (and eventually explicitly) come to position them as having lesser ability to bear witness to natural phenomena. By focusing on the Other, this has the further effect of normalizing and naturalizing the ways in which science is dominion of Man:

In order for the modesty... to be visible, the man - the witness whose accounts mirror reality - must be invisible, that is, an inhabitant of the potent "unmarked category," which is constructed by the extraordinary conventions of self-invisibility... This self-invisibility is the specifically modern, European, masculine, scientific form of the virtue of modesty. (Haraway, 1997, p. 23) 
Secondly, as Dr. Apffel-Marglin states, one must also be educated to participate. As this required access to wealth, those of lower class would also be excluded (see also Haraway, 1997; Shapin \& Schaffer, 1985). While one could say that that was there-then and this is here-now, it is nonetheless important to consider how science and science education's historicity continues to shape the here-now and the there-thens to-come as we move forward. While science education is increasingly perceived as being enacted as a practice for all students (see Aikenhead \& Elliot, 2010), it is nonetheless important to continue considering how the all in such statements are articulated, especially when science education scholars continue referring to WMS as white male science (Pomeroy, 1994; see also McKinley, 2000; Sammel, 2009).

Accordingly, while the practices of who gets to do science have explicitly changed, many of the implicit meanings remain when we consider the ways in which the how of science were and continue to be framed. As Frédérique makes explicit, the practice of being a modest witness cannot be separated from the socio-political context of the time in Western Europe: particularly from what was happening within the sphere of the Church. Following the establishment of the Protestant Church, Western Europe was thrown in turmoil: a powerful addiction to certainty and competing claims of holding the One Truth would see Catholics and Protestants kill each other "with gusto, brutality, and horror" for a thirty year period. Following the Thirty Years' War, there was need of a system of governance that would not bound to either religion: in the creation of the scientific laboratory, we would also see the birth of secularism. As Dr. Apffel-Marglin puts it, this came to shape the very practice of the laboratory in its infancy in profound ways: "it was very simple: if you talked about religion, you might kill each other". However, as mentioned earlier within this chapter, the creation of secularity as mutually exclusive from spirituality had consequences then and now: practices, like TEK and IWLN, that do not see separate spirit and matter are implicitly (and sometimes explicitly) not welcome within the formal spaces of science. This trend, while far less explicit continues to bear on educational spaces today ${ }^{20}$ : recall from Chapter 3 that there continue to be many science education scholars, as well as science educators who frame practices other-than-WMS as less valid (e.g., Cobern \& Loving, 2008; Siegel, 2001).

In these instances, it can be said that there continue to be traces of what Frédérique refers to as the One Truth: "religious certainty has been 
transposed into a new key, to use a musical metaphor". ${ }^{21}$ The aforementioned claims of validity do not come to frame WMS as being more valid in particular moments within the multicultural science education debate, but rather as a general and a "universal" which is a priori to knowing and being. It could be stated that the transposition of power from the Church to the laboratory as instrument of the State did not address or redress Western Europe's addiction for certainty at the time, but rather resituated and differentially produced the ways in which one had access to the One Truth. It is for this reason that Spivak (1976) cautions against the (too) rapid evacuation of a concept, category, or framework: left unaddressed, its problematics often follow us in ghastly and ghostly manners to reassert themselves elsewhere albeit differently (see also Derrida, 1994/2006). The calling into question of the claim of "most valid" is not to deny it, but rather resituate it by asking the questions of when and where it is most productive; few science education scholars deny the pragmatic effectiveness of WMS in making knowledge claims about nature. However, science is indebted to and weighed down by the ways in which the One Truth continue to (re)shape it: science education continues to be a space which dialectically subsumes and sutures over TEK and IWLN as a means of resolving difference and reasserting WMS as a more nuanced version of the One Truth in an ever-diversifying world.

\section{Conclusion: Positing, Accounting for and Being Accountable to an Ontology in Science Education}

To address the past (and future), to speak with ghosts, is not to entertain or reconstruct some narrative of the way it was, but to respond, to be responsible, to take responsibility for that which we inherit (from the past and the future), for the entangled relationalities of inheritance that "we" are, to acknowledge and be responsive to the noncontemporaneity of the present, to put oneself at risk, to risk oneself (which is never one or self), to open oneself up to indeterminacy in moving toward what is to-come. Responsibility is by necessity an asymmetrical relation/doing, an enactment, a matter of différance, of intra-action, in which no one/no thing is given in advance or ever remains the same. Only in this ongoing responsibility to the entangled other, without dismissal (without 'enough already!'), is there the possibility of justice-to-come. (Barad, 2010, pp. 264-265, emphasis in original) 
To posit Cartesianism as an ontology in science education is to inevitably speak with ghosts: that which we inherit from science's "beginnings" haunt us. Because the homework of response-ability begins from where we are, it is not only significant to engage in a creative archaeology dig into the pasts passed over that constitute us, but it is part of our responsibility as it is to "take responsibility for that which we inherit" (Barad, 2010 , p. 264): what we inherit is irreducibly part of who we are and who we are becoming as science educators. Repeating a question posed earlier in this chapter, when pasts are passed over, but still come to constitute the here-now of contemporary practice, what ghosts which continue to haunt science education are being chased away?

As explored through tinkering with an expert interview with Dr. Apffel-Marglin, Cartesianism cannot simply be reduced to set of belief that are individually held but rather a structure: the scientific revolution operationalized and naturalized Descartes' epistemology through the technological practices of the laboratory, the modest witness, and the objective style of writing. More significantly, these practices cannot and should not be so easily disentangled from socio-material practices of Western Modern Europe which lead to and surrounded its operationalization (e.g., the enclosure movement, the Thirty Years' War). The making common of Cartesianism not only (fore)closes the possible possibilities for responding to Indigenous science to-come, but also the ability to account for and be accountable to the ontology of WMS and what it produces: repeating the mantra of the last chapter, "how reality is understood matters" (Barad, 2007, p. 205).

Significantly, in this contemporary moment in science education, the presented and enacted conceptions of nature-cultures makes possible and palatable the ongoing dispossession and devastation of Indigenous Land, as well as the erasure of Indigenous peoples (see Bang \& Marin, 2015). Diffracting Dr. Frédérique Apffel-Marglin's account through the logics of the multicultural science education debate reveals this dispossession and devastation to have been the case from the very "beginning" of Western modernity: Indigenous erasure is not strictly a feature of contemporary science education, but rather part of the inheritance which shapes who we are and can be. The scientific revolution could not be separated from the removal of peoples from Land and (forceful) denegation of their waysof-knowing-in-being. These logics which would later come to inform ongoing practices of (neo-)colonialism. It bears repeating, the task at hand the task at hand is not to begin a new relation but rather to engage 
the relation anew: WMS and Indigenous science are always already in relation.

It is for that reason that responding to Indigenous science to-come is not achieved "through the realization of some existing possibility, but through the iterative reworking of im/possibility" (p. 265): we are working against centuries of history in which Cartesianism and its consequences have been normalized and naturalized. While there is no singular solution to (re)opening the norms of responsiveness towards Indigenous science to-come, positing an ontology paves pathways to engage with the $\mathrm{im} /$ possibility of being wholly accountable to and ethically responsive by coming-to-perceive the very possibility of ontological otherness, as well as accounting for the ways-of-knowing-in-being which foreclose such possibility. To reiterate from the previous chapter, situating science education ontologically by positing an ontology is not about who is right or who is wrong, nor is it about a renewed commitment to relativism. Rather, it is about coming-to-recognize a plurality of possibilities (and problematics), and in turn, it means being accountable to how scientific knowledge is produced, producible, and what it produces in turn within and beyond the science education classroom. For example, thinking with Frédérique Apffel-Marglin allowed for differential considerations in the conceptual baggage that comes with the metaphysics of modernity, not to dismiss or do-away with these ways-of-knowing-in-being but rather come to work with/in the structures that (re)produce and are reproduced by science education in order to (re)open them to Indigenous science to-come. These include the ways in which the home in the homework of responseability manifests as absent presences: "uncommon" political, religious, economic, and military practices (e.g., the enclosure) that are enfolded and co-constituting "common" scientific technologies and practices (e.g., modest witness) of a non-dissociable past and present.

As the ability to respond to Indigenous science to-come requires an "ongoing responsibility to the entangled other, without dismissal (without 'enough already!')" (Barad, 2010, pp. 264-265), the task of de/colonizing our inheritances within science education is never fully over. 


\section{Notes}

1. As Spivak(1976) reminds us, the language we possess also possesses us: to (too) simply abandon a particular does not mean that it has abandoned us. If the thoughts we have and by which we are had are part of the problem, it is not so simple to think about how we think without using the thing with which we think. This is to say that science education is irreducibly related to Cartesianism and that attempts to move beyond this ontology and its consequences must simultaneously work to understand and address it, as well as its entangled productions.

2. The scare quotes here are intentional as origins are forever deferred and differing (see Derrida, 1976; Kirby, 2011). Further, as signalled in the previous chapter, the fetish for origins is irreducibly bound to (neo-)colonial ways-of-knowing-in-being (see TallBear, 2013). Dr. ApffelMarglin makes explicitly clear that the "birth of modernity" is not an "origin" in the conventional sense but rather a partial and contingent origin: $a$ historical moment in which modernist thinking is operationalized (see Apffel-Marglin, 2011).

3. Along similar lines, Sara Ahmed (2006) succinctly states:

The word inheritance includes two meanings: to receive and to possess. In a way, we convert what we receive into possessions, a conversion that often "hides" the conditions of having received, as if the possession is "already there." (p. 125)

The task of inheritance is to also consider that which we have received which no longer appears as such, specifically that which we receive from (or, more precisely, at the expense of) the other.

4. Once again, the mantra of beginning some-where and some-time is a reminder that we are always already within the question of Indigenous ways-of-knowing-in-being within science education. In turn, there is a multiplicity of locations (both temporal and geographical) from which we can approach the question productively.

Furthermore, this specific reminder, returning to the introduction of the very first chapter, also serves to hint at the ways in which the present is not only here-now but is always entangled with/in various there-thens: that these elsewheres and elsewhens are not strictly cognitive objects to be known (i.e., historical and geographical facts) but are ontologically coconstitutive of our contemporary present, here and now. As Karen Barad (2010) states, "to address the past (and future), to speak with ghosts, is not to entertain or reconstruct some narrative of the way it was, to respond, to be responsible, to take responsibility for that which we inherit ..." (Barad, 2010, p. 264, emphasis in original). This bears particular 
significance as we take up and are called to take seriously pasts already passed over which continue to haunt science education's present, as if a spectre or a ghost, reaching out to future(s)-to-come. This is to say, to take the task of attending to the absent presences within the history of science (or at least those that are usually absent within the common sensical narrative of science): as they also have bearing on what science education was, is, and is becoming. As the absent present relationships between science and Indigeneity is always already, the work of attending to the inheritances which haunt science education is not without significance: they are "entangled relationalities of inheritance that 'we' are" (Barad, 2010 , p. 264, emphasis in original).

This work of inheritance as responsibility at the ontological turn points towards Derrida's (1994/2006) concept of hauntology, a (near-) homonym to ontology that is meant to defer and differ ontology's conventional "discourse on the Being of beings" (p. 63) to embrace that which exceeds it: the spectral. Significantly, hauntings are not simply concepts: Barad (2010) provides empirical evidence via quantum field theory. Hauntings are indeterminacies in the ways in which space-timematter materializes: a particle can be in a state of superposition such that it is simultaneously here, there, now, and then (including a there-then in the future tense, see Barad, 2010for further). Importantly, hauntology troubles the possibility of ontology being a singular (Cartesian) affair:

To haunt does not mean to be present, and it is necessary to introduce haunting into the very construction of a concept. Of every concept, beginning with the concept of being and time. That is what we would be calling a hauntology. Ontology opposes it only in a movement of exorcism. Ontology is a conjuration. (Derrida, $1994 / 2006$, p. 202)

Barad further suggests that: "every concept is haunted by its mutually constituted excluded other”. (Barad, 2010, p. 253). Where ontology often comes to stand in for epistemic realism, as explored within the previous chapter, it becomes useful to think with and through the notion of ontology as conjuration or exorcism. Throughout Specters of Marx, Derrida (1994/2006) invokes multiple meanings to the concept of conjuring. It is at once the oath solemnly sworn in secrecy to struggle against a greater power, an incantation or summoning of a spirit, as well as an exorcism. Importantly, an "effective exorcism pretends to declare the death only in order to put to death" (Derrida, 1994/2006, p. 59). When pasts are passed over, but still come to constitute the here-now of 
contemporary practice, it is worth asking: what ghosts might have science education been chasing away?

5 . Further, it became an opportunity to experiment with more creative ways of representing, and more specifically storying, Indigenous place-based education (see Higgins \& Madden, 2019).

6. As explored in Higgins, Madden, Bérard, Lenz Kothe, and Nordstrom (2017), methodological research "design" often prescriptively and prohibitively continues to act as a signifier that sutures over the signified processes of designing and doing research. "Design" often signals $a$ method that is exists a priori to research, "a stand-alone, instrumental set of research practices" (St. Pierre, 201lb, p. 52). This also includes and encompasses all of its conceptual apparatus (such as, in this case, "expert" and "expert knowledge").

Rather, the practice of methodological de/sign differs and defers that which design comes to signify: design as pre-existing, design as separate or separable from other aspects of research, and design as a means to achieve and justify the ends (see also Derrida, 1976; Spivak, 1976). Because methodological fabric is also a fabrication-a performative and non-separable enactment of the interconnected space between theory, practice, and ethics-methodological design is always already open to be deconstructed and re(con)figured.This is of particular significance in spaces of de/colonizing education. Highlighting the ways in which the disciplines discipline what counts as knowledge and, more to the point, knowledge production processes, Smith et al. (2016) ask, "are methodologies simply new technologies of cultural assimilation?" (p. 133). To (re)open the conceptual apparatuses of methodology allows for the possibility of addressing lingering colonial referents within science education (see Higgins \& Kim, 2019).

7. Such a tinkering can be understood both as tinkering within the narrative presented throughout her book, but also tinkering with it in relation to the multicultural science education debate.

8. Butler's criticism of particular cultural uses of "natural facts" still stands today as "natural facts are always informed by cultural bias" (Butler in Kirby, 2011, p. 94). As this is "one of the most important contributions that scholars such as Butler have made, ... any return to the question of Nature will need to accommodate such insights rather than put them aside" (p. 94). Nonetheless, the opening of other possibilities beyond the natural/cultural divide allowed by this minor concession sees productive uses in her later work (e.g., Butler, 2010); with an always present cautionary note against the "seductive slide that conflates representation, models, and signs that substitute for material objects, with the objects themselves" (Butler in Kirby, 2011, p. 74). 
9. This can be read as a form of strategically occupying an essentializing space (see Spivak, 1993/2009). However, Spivak (1993/2009) reminds, "the strategic use of essentialism can turn into an alibi for proselytizing academic essentialisms" (p. 4) without the persistent critique of that which is being essentialized throughout, "even when it seems that to remind oneself of it is counterproductive" (p. 4). Where Frédérique's interview challenges throughout the production of the academic subject of knowledge (i.e., expert), the strategic use essentialism remains nonetheless fraught, being a pharmakon: at once panacea and poison (see Spivak, 1976).

10. See Chapter 7 for a lengthier discussion on the ways in which the Derridean statement that il n'y a pas de hors-texte is a complex one within science and science education spaces. Importantly, there not being an outside of Culture does not preclude Nature unless with subscribe to a mutual exclusivity to two (see Kirby, 2011). Rather, it invites a consideration of the ways in which nature is not only within the realm of Culture at the individual cognitive level and the social discursive level (via the concepts we hold that also hold us, but also that nature is rarely "pure" and beyond the effects of culture (e.g., anthropogenic landscapes) or unable to produce cultural meaning. This latter is of deep significance to (re)opening science education to Indigenous science to-come (e.g., other-than-humans as teachers).

11. It is important to distinguish between a Man (i.e., a Western European male), the Man, (i.e., the shadowy figure in Marxist nightmares which appears to control nearly all from behind the scenes), and Man as articulated here. The first two emerge from use of the representational logic of the mirror such that they are representative of $a n$ individual, whether real or imagined, who is a separate or separable agent (i.e., what Nietzsche refers to as the "individual of will") benefitting from the power systems articulated. The latter term speaks to the complex and capillary circulation of ways-of-knowing-in-being that uphold and operationalize systems that center Man and Western modernity (e.g., Eurocentrism, anthropocentrism, patriarchy).

12. Diffusion can be understood as a scientific phenomena and concept which describes the movement of a substance from an area of high concentration to an area of low concentration. Importantly, where a diffusionist model (e.g., Blaut, 1993) employs the concept of diffusion productively to describe the colonizing movement of Western thought outwards of Europe, it is also important to not conflate the passive qualities of the scientific phenomena and the ways in which Eurocentrism operate actively: ongoing (neo-)colonial practices are not experienced as passive "transmission" of Euro-Western values, beliefs, and traditions. As explored in the 
previous chapter (i.e., the ways in which common sense is made common), it is important to recognize that Eurocentrism is active, forceful, and violent (both literally and otherwise); it is also agentically distributed, albeit differentially: Eurocentrism is a "consciousness in which all of us have been marinated" (Battiste, 2005, p. 124, emphasis mine).

13. As Colebrook (2008) suggests, Butler's (1990) Gender Trouble is often (too simply) read as anti-ontological as it resituates that which is problematically enacted as biological determinism (i.e., sex) into the realm of discourse (i.e., through gender performativity). Taking a cue from Foucaultian critique (see Chapter 4), it is fair to state that Butler does not wholly jettison ontology altogether, but rather ontology like that (i.e., a Cartesian ontology in which matter precedes meaning). In turn, Colebrook's (2008) reading of Butler suggests that materiality (i.e., ontology) emerges as co-constituted by discourse (i.e., epistemology), subverting dominant epistemological and ontological constructions and enactments rather than negating them.

14. During our interviews, Frédérique Apffel-Marglin shared the following regarding what Newton had to forego to maintain epistemic power and privilege within his geo-temporal contexts:

It was just delightful for me to learn of that, by reading Isabelle Stengers' (2001) little play about Newton titled La Guerre des Sciences aura-t-elle lieu?, that one of Newton's descendants needed money in 1930 and found in Newton's attic unpublished papers, manuscripts, and other works. He auctioned them to make money. So it was then bought and studied. This work was spiritual in tone: gravity was a spiritual power. Of course, he could not go public with this. So it was not to be found out or made public until these papers were sold and people took time to study them.

Deeply intrigued, I began to read Stengers' (2001; Prirogine \& Stengers, 1984) work, and deeper into the question of Newton and his complex and complicated relation to science. Elsewhere (Higgins \& Tolbert, 2018), writing up nascent leads on the this, I ask:

... what might it mean to recast science as a practice that is not oppositionally defined against spirituality and attend to the ways in which spirituality always already been included within WMS? Prigogine and Stengers state that this is the case for one of the most emblematic men of science whose way-of-being-scientific has acted as differential mould for what it means to be a scientist: Isaac Newton. They state that many "did not know the strange 
story behind the Newtonian forces! For behind Newton's cautious declaration-'I frame no hypotheses'-concerning the nature of the forces lurked the passion of an alchemist." This came to light last century when one of Newton's descendants, Gerald Wallop, the 9th Earl of Portsmouth needed funds in the midst of a costly divorce and put up Newton's unpublished papers for auction in 1936. Following their purchase and analysis, John Maynard Keynes would go on to state that Newton was "not the first of the age of reason" but "the last of the magicians." Stated otherwise, his approach to science was not devoid of spirituality, but rather the norms of becoming-scientist at the time made it such that he could not openly discuss the multilogical approach that informed and fueled his thinking (as part of the practice of modest witnessing). His unpublished work along these lines would be hidden and stored by generations of family in hopes that a time would arrive in which it might be received: a latent safeguard that he perhaps hoped would allow us to dispel the myth the Isaac Newton was Newtonian. Stengers invites us to consider if the science wars over "what counts" will have had happened if this insight and rupture would allow us to complicate science's ongoing relation to Newton by reinserting the ways in which the man exceeded the concept. (p. 283)

Here, we have yet another rich example of how science is always already entangled with/in and prismatically producing its own norms of articulation (i.e., what can be said and done, and what cannot). Importantly, if we continue to produce scientists (as well as science educators) in the image of Newton, it bears leveraging his hope for a science-yet-to-come in which logics deemed other might come to bear on the knowledge production process. While we need unsettle our inheritances in science education, some inheritance unsettle themselves if we learn to attend to the ways in which deconstruction always already happens.

15. Furthermore, while Newton's subject position is produced by the there-then of the time and place, knowing Newton as scientist cannot be disentangled from the here-now: he continues to be, after Stengers (2001), the mould from which scientists are cast.

16. Considering science and science education as entangled with/in legaljuridical modes provides insight into the ongoing practice of dialectic rather than dialogue, as explored within Chapter 3, as scientific subjects are required to dismantle their opposition's arguments before a "court" of their peers (e.g., peer review).

17. Recall that, as explored within Chapter 4, the laboratory is always already the context in which scientific knowledge-practices are produced and enacted, whether the lab be real or imaginary. As van Eicjk and Roth 
(2007) suggest, the generation of scientific knowledge requires that the context under observation be transcended and treated as if it were static, singular, and homogenous. In turn, scientific knowledge praxis requires that the context of its application also be treated as such. When considered as a practice which is also translated into science education, it is important to consider the (re)production of the double(d) subject of the laboratory: both Nature as subject of inquiry and scientist (or student-thinking-like-a-scientist) as inquiring subject.

18. Apffel Marglin (2011) states that if colonization was so effective, it was because it was perfected through its internal application within Western Europe before it was exported to Western Europe's Others. Along similar notes, during her talk titled Four Theses on Posthuman Feminism at UBC, Rosi Braidotti stated that the Holocaust was "colonialism coming home" (28 January 2015). The point to be made here is that (neo-)colonial systems come to affect us all, even if they do not affect us all in the same way (see Battiste, 2005, 2013b; Donald, 2012; Freire, 1973/2000): they differentially inflect our respective (re)production as de/colonizing subjects.

19. In turn, it is productive to address the ways in which the mind/body binary come to operate within science education when working within and against Cartesianism. For example, recall that in Chapter 3 you were encouraged, as a reader, to also pay attention to the affective ways (e.g., emotive, sensory) in which information registered upon their body. If science is to be framed as a human practice (see Aikenhead, 2006), it is worthwhile and important to consider, account for, and be accountable to the plural and diverse ways in which we are human.

20. While not directly discussing spaces of science education, Marker's (2006) After the Makah Whale Hunt is a rich exemplar of the complexities and complications which arise when bringing in Indigenous knowledges and knowledge holders into schools to discuss other-than-human members of a local ecology. As school spaces are secular (through separation of Church and State), but seen as neutral and the norm, the inclusion of IWLN and its interconnectedness of spirit and matter is brought into sharp relief and becomes a site in which Eurocentrism plays out in diverse manners (e.g., excluding knowledge and knowledge holders, only including such lesson if it omits its co-constitutive spiritual dimension).

21. Or, as Stengers (2001) puts it, while history does not repeat itself, it nonetheless repeats. 


\section{REFERENCES}

Ahmed, S. (2006). Queer phenomenology: Orientations, objects, others. Durham, NC: Duke University Press.

Aikenhead, G. S. (2006). Science education for everyday life. London, ON: Althouse Press.

Aikenhead, G. S., \& Elliot, D. (2010). An emerging decolonizing science education in Canada. Canadian Journal of Science, Mathematics and Technology Education, 10(4), 321-338.

Aikenhead, G. S., \& Michell, H. (2011). Bridging cultures: Indigenous and scientific ways of knowing nature. Toronto, ON: Pearson Canada Inc.

Aikenhead, G. S., \& Ogawa, M. (2007). Indigenous knowledge and science revisited. Cultural Studies of Science Education, 2(3), 539-591.

Apffel-Marglin, F. (2011). Subversive spiritualities: How rituals enact the world. New York, NY: Oxford University Press.

Bang, M., \& Marin, A. (2015). Nature-culture constructs in science learning: Human/non-human agency and intentionality. Journal of Research in Science Teaching, 52(4), 530-544.

Barad, K. (2000). Reconceiving scientific literacy as agential literacy. In R. Reed \& S. Traweek (Eds.), Doing Science+Culture (pp. 221-258). New York, NY: Routledge.

Barad, K. (2007). Meeting the universe halfway: Quantum physics and the entanglement of matter and meaning. Durham, NC: Duke University Press.

Barad, K. (2010). Quantum entanglements and hauntological relations of inheritance: Dis/continuities, spacetime enfoldings, and justice-to-come. Derrida Today, 3(2), 240-268.

Barad, K. (2011). Erasers and erasures: Pinch's unfortunate 'uncertainty principle'. Social Studies of Science, 4l(3), 443-454.

Battiste, M. (2005). You can't be the global doctor if you're the colonial disease. In P. Tripp \& L. J. Muzzin (Eds.), Teaching as activism (pp. 121-133). Montreal, QC: Queen's University Press.

Battiste, M. (2013a). Deconstruction and reconstruction: Roles, responsibilities and implications of a decolonizing framework. Retrieved from http://www. indigenouseducation.educ.ubc.ca/transformation/indigenous-perspectives/ on $11 / 22 / 2012$.

Battiste, M. (2013b). Decolonizing education: Nourishing the learning spirit. Saskatoon, SK: Purich Publishing.

Blaut, J. (1993). The colonizer's model of the world: Geographical diffusionism and Eurocentric history. New York, NY: Guilford Press.

Bogner, A., Littig, B., \& Menz, W. (Eds.). (2009). Interviewing experts. Basingstoke, UK: Palgrave Macmillan.

Butler, J. (1990). Gender trouble. London, UK: Routledge. 
Butler, J. (2005). On giving an account of oneself. New York, NY: Fordham University Press.

Butler, J. (2010). Frames of war: When is life grievable?. London, UK: Verso.

Cajete, G. (1994). Look to the mountain: An ecology of indigenous education. Durango, CO: Kivaki Press.

Cajete, G. (2000). Native science: Natural laws of interdependence. Santa Fe, NM: Clear Light Books.

Cobern, W. W., \& Loving, C. C. (2008). An essay for educators: Epistemological realism really is common sense. Science \& Education, 17, 425-447.

Colebrook, C. (2008). On not becoming man: The materialist politics of unactualized potential. In S. Alaimo \& S. Hekman (Eds.), Material feminisms (pp. 52-84). Bloomington, IN: Indiana University Press.

Derrida, J. (1976). Of grammatology (G. C. Spivak, Trans.). Baltimore, MD: John Hopkins University Press.

Derrida, J. (1994/2006). Specters of Marx: The state of the debt, the work of mourning, of the new international (P. Kamuf, Trans.). New York, NY: Routledge.

Donald, D. (2012). Indigenous Métissage: A decolonizing research sensibility. International Journal of Qualitative Studies in Education, 25(5), 533-555.

Foucault, M. (1977). Discipline and punish: The birth of the prison. London, UK: Allen Lane.

Foucault, M. (1979). Truth and power. In M. Morris \& P. Patton (Eds.), Power, truth, strategy (pp. 29-48). Sydney, NSW: Feral Publications.

Freire, P. (1973/2000). Pedagogy of the oppressed. New York, NY: Continuum International Publishing Group.

Haraway, D. (1997). Modest_Witness@Second_Millennium.FemaleMan_Meets_ OncoMouse. New York, NY: Routledge.

Higgins, M. (2014). De/colonizing pedagogy and pedagogue: Science education through participatory and reflexive videography. Canadian Journal of Science, Mathematics and Technology Education, 14(2), 154-171.

Higgins, M., \& Kim, E. J. (2019). De/colonizing methodologies in science education: Rebraiding research theory-practice-ethics with indigenous theories and theorists. Cultural Studies of Science Education, 14(1), 111-127.

Higgins, M., \& Madden, B. (2019). Refiguring presences in Kichwa-Lamista territories: Storying with Indigenous place. In C. Taylor \& A. Bayley (Eds.), Posthumanism and higher education: reimagining pedagogy, practice and research (pp. 293-312). Basingstoke, UK: Palgrave Macmillan.

Higgins, M., Madden, B., Bérard, M.-F., Lenz Kothe, E., \& Nordstrom, S. (2017). De/signing research in education: Patchwork(ing) methodologies with theory. Educational Studies, 43(1), 16-39.

Higgins, M., \& Tolbert, S. (2018). A syllabus for response-able inheritance in science education. Parallax, 24(3), 273-294. 
Higgins, M., Wallace, M., \& Bazzul, J. (2019). Staying with the trouble in science education. In C. Taylor \& A. Bayley (Eds.), Posthumanism and higher education: reimagining pedagogy, practice and research (pp. 155-164). Basingstoke, UK: Palgrave Macmillan.

Hodson, D. (1993). In search of a rationale for multicultural science education. Science Education, 77(6), 685-711.

Kirby, V. (2011). Quantum anthropologies: Life at large. Durham, NC: Duke University Press.

Kirby, V. (2012). Initial conditions. Differences, 23(3), 197-205.

Lather, P. (2007). Getting lost: Feminist efforts toward a double(d) science. New York, NY: State University of New York.

Latour, B. (1993). We have never been modern. Cambridge, MA: Harvard University Press.

Latour, B. (2004). Politics of nature: How to bring the sciences into democracy. Cambridge, MA: Harvard University Press.

Lewis, B., \& Aikenhead, G. (2001). Introduction: Shifting perspectives from universalism to cross-culturalism. Science Education, 85, 3-5.

Marker, M. (2006). After the Makah whale hunt: Indigenous knowledge and limits to multicultural discourse. Urban Education, 41(5), 482-505.

Mazzocchi, F. (2006). Western science and traditional knowledge. EMBO Reports, 7(5), 463-466.

Mazzocchi, F. (2008). Analyzing knowledge as part of a cultural framework: The case of traditional ecological knowledge. Environments Journal, 36(2), 39-57.

McKinley, E. (2000). Cultural diversity: Masking power with innocence. Science Education, 85(1), 74-76.

McKinley, E. (2007). Postcolonialism, Indigenous students, and science education. In S. K. Abell \& N. G. Lederman (Eds.), Handbook of research on science education (pp. 199-226). Mahwah, NJ: Lawrence Erlbaum.

Peat, D. (2002). Blackfoot physics: A new journey into the Native American universe. Newbury Port, MA: Weiser Books.

Peat, F. D. (2007). Pathways of chance. Pari, IT: Pari Publishing.

Prigogine, I., \& Stengers, I. (1984). Order out of chaos. New York, NY: Bantam Books.

Pomeroy, D. (1994). Science education and cultural diversity: Mapping the field. Studies in Science Education, 24, 49-73.

Sammel, A. (2009). Turning the focus from 'other' to science education: Exploring the invisibility of whiteness. Cultural Studies of Science Education, 4, 649-656.

Shapin, S., \& Schaffer, S. (1985). Leviathan and the air-pump. Princeton, NJ: Princeton University Press.

Siegel, H. (2001). Multiculturalism, universalism, and science education: In search of common ground. Science Education, 86, 803-820. 
Smith, L. T. (1999/2012). Decolonizing methodologies: Research and Indigenous People (2nd ed.). London, UK: Zed Books.

Smith, L. T., Maxwell, T. K., Puke, H., \& Temara, P. (2016). Indigenous knowledge, methodology and mayhem: What is the role of methodology in producing Indigenous insights? A discussion from mātauranga Māori. Knowledge Cultures, 4(3), 131-156.

Spivak, G. C. (1976). Translator's preface. In J. Derrida, Of grammatology (G. C. Spivak, Trans.) (pp. ix-lxxxvii). Baltimore, MD: Johns Hopkins University Press.

Spivak, G. C. (1993/2009). Outside in the teaching machine. New York, NY: Routledge.

Spivak, G. C. (1999). A critique of postcolonial reason. Cambridge, MA: Harvard University Press.

Stengers, I. (2001) La guerre des sciences aura-t-elle lieu?: Scientifiction. Paris, France: Le Seuil-Les Empêcheurs de Penser en Rond.

St. Pierre, E. A. (201la). Post qualitative research: The critique and the coming after. In N. K. Denzin \& Y. S. Lincoln (Eds.), The SAGE handbook of qualitative research (4th ed., pp. 611-626). Thousand Oaks, CA: Sage.

St. Pierre, E. A. (2011b). Refusing human being in humanist qualitative inquiry. In N. K. Denzin \& M. D. Giardina (Eds.), Qualitative inquiry and the global crisis (pp. 40-55). Walnut Creek, CA: Left Coast Press.

TallBear, K. (2013). Native American DNA: Tribal belonging and the false promise of genetic science. Minneapolis, MN: University of Minnesota Press.

van Eijck, M., \& Roth, W. M. (2007). Keeping the local local: Recalibrating the status of science and traditional ecological knowledge (TEK) in education. Science Education, 91(6), 926-947. 
Open Access This chapter is licensed under the terms of the Creative Commons Attribution 4.0 International License (http://creativecommons.org/licenses/ by/4.0/), which permits use, sharing, adaptation, distribution and reproduction in any medium or format, as long as you give appropriate credit to the original author(s) and the source, provide a link to the Creative Commons license and indicate if changes were made.

The images or other third party material in this chapter are included in the chapter's Creative Commons license, unless indicated otherwise in a credit line to the material. If material is not included in the chapter's Creative Commons license and your intended use is not permitted by statutory regulation or exceeds the permitted use, you will need to obtain permission directly from the copyright holder.

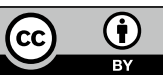

